University of Nebraska - Lincoln

DigitalCommons@University of Nebraska - Lincoln

USDA Forest Service / UNL Faculty Publications U.S. Department of Agriculture: Forest Service -National Agroforestry Center

2012

Marine vertebrates from the Hartland Shale (Upper Cretaceous: Upper Cenomanian) in southeastern Colorado, USA

\author{
Matthew Nagrodski \\ DePaul University \\ Kenshu Shimada \\ DePaul University \\ Bruce A. Schumacher \\ USDA Forest Service
}

Follow this and additional works at: https://digitalcommons.unl.edu/usdafsfacpub

Part of the Forest Sciences Commons

Nagrodski, Matthew; Shimada, Kenshu; and Schumacher, Bruce A., "Marine vertebrates from the Hartland Shale (Upper Cretaceous: Upper Cenomanian) in southeastern Colorado, USA" (2012). USDA Forest Service / UNL Faculty Publications. 161.

https://digitalcommons.unl.edu/usdafsfacpub/161

This Article is brought to you for free and open access by the U.S. Department of Agriculture: Forest Service -National Agroforestry Center at DigitalCommons@University of Nebraska - Lincoln. It has been accepted for inclusion in USDA Forest Service / UNL Faculty Publications by an authorized administrator of DigitalCommons@University of Nebraska - Lincoln. 


\title{
Marine vertebrates from the Hartland Shale (Upper Cretaceous: Upper Cenomanian) in southeastern Colorado, USA
}

\author{
Matthew Nagrodski ${ }^{a}$, Kenshu Shimada ${ }^{a, b, c, *}$, Bruce A. Schumacher ${ }^{c, d}$ \\ ${ }^{a}$ Department of Environmental Science and Studies, DePaul University, 1110 West Belden Avenue, Chicago, IL 60614, USA \\ ${ }^{\mathrm{b}}$ Department of Biological Sciences, DePaul University, 2325 North Clifton Avenue, Chicago, IL 60614, USA \\ ' Sternberg Museum of Natural History, Fort Hays State University, Hays, KS 67601, USA \\ ${ }^{\mathrm{d}}$ USDA Forest Service, 1420 East Third Street, La Junta, CO 81050, USA
}

\section{A R T I C L E I N F O}

\section{Article history:}

Received 27 November 2011

Accepted in revised form 7 March 2012

Available online $\mathrm{xxx}$

\section{Keywords:}

Cenomanian

Greenhorn Limestone

Late Cretaceous

Palaeoecology

Western Interior Seaway

\begin{abstract}
A B S T R A C T
The Hartland Shale Member of the Greenhorn Limestone was deposited in the middle of the Late Cretaceous Western Interior Seaway of North America. Rock samples rich in micro-vertebrate fossils were collected from the lower part of the Hartland Shale (ca. 94.6 Ma: early Late Cenomanian) in southeastern Colorado, USA. Through acid treatment of the rock samples, 25 marine vertebrate taxa are identified including chondrichthyans, osteichthyans, and a reptile. Chondrichthyans are represented by seven species: Ptychodus anonymus, Squalicorax curvatus, Carcharias saskatchewanensis, Archaeolamna kopingensis, Cretoxyrhina mantelli, Cretomanta canadensis, and Rhinobatos incertus. Osteichthyan fishes consist of 17 taxa: Micropycnodon kansasensis, cf. Palaeobalistum sp., Caturidae indet., Protosphyraena sp., Plethodidae indet., Elopopsis sp., Pachyrhizodus minimus, cf. Pachyrhizodus sp., Albulidae indet., Cimolichthys nepaholica, Enchodus cf. E. gladiolus, E. cf. E. shumardi, Apateodus sp., and four unidentified teleosts. The only reptilian recognized is the small aquatic lizard Coniasaurus crassidens (Dolichosauridae). The taxonomic composition of the Hartland Shale fauna is similar overall to the extensively sampled, underlying mid-Cenomanian Lincoln Limestone fauna in Colorado and Kansas, although the occurrence of Apateodus and Cimolichthys from the Hartland Shale is notable as they represent geologically the oldest record for the two genera. The vertebrates identified are mostly carnivores that include piscivorous and durophagous forms, providing new insights into the trophic structure of the palaeocommunity.
\end{abstract}

(c) 2012 Elsevier Ltd. All rights reserved.

\section{Introduction}

The Western Interior Seaway is an epicontinental sea that extended from north to south through the middle of North America during the Late Cretaceous. It developed when the continent was flooded from the north (Arctic Ocean) and south (Atlantic-Tethyan seas), and merged in the midcontinent during the early Middle Cenomanian (Kauffman and Caldwell, 1993). It served as habitat for a diversity of marine invertebrates including ammonoid cephalopods and inoceramid bivalves as well as many marine vertebrates including sharks, bony fishes, and tetrapods, such as plesiosaurs, mosasaurs, sea turtles, and aquatic and shore birds (e.g., Everhart, 2005; Cumbaa et al., 2010).

\footnotetext{
* Corresponding author. Department of Environmental Science and Studies, DePaul University, 1110 West Belden Avenue, Chicago, IL 60614, USA. Tel.: +1773 325 4697; fax: +1 7733257448 .

E-mail addresses: matt.nagrodski@gmail.com (M. Nagrodski), kshimada@ depaul.edu (K. Shimada), baschumacher@fs.fed.us (B.A. Schumacher).
}

A fossil assemblage from the Niobrara Formation (Upper Coniacian-Lower Campanian) in Kansas is arguably the best documented vertebrate fauna from the Western Interior Seaway where over 70 fish and 40 tetrapod taxa have been recorded to date (Russell, 1988; Everhart, 2005; Shimada and Fielitz, 2006). A recent study (Cumbaa et al., 2010) shows that at least 70 vertebrate taxa were present in the seaway during the mid-Cenomanian. This study also reveals that the time frame marked the onset of the "Niobrara fauna" because the mid-Cenomanian fauna includes approximately ten species that are represented in it (Cumbaa et al., 2010).

The Hartland Shale Member of the Greenhorn Limestone (Fig. 1A) in southeastern Colorado was deposited in the middle of the Western Interior Seaway. It lies immediately above the Lincoln Limestone Member of the same formation where the composition of vertebrate taxa has been extensively studied previously (e.g., Liggett et al., 2005; Shimada et al., 2006; Shimada and Martin, 2008). Although a few fish and plesiosaur remains have been noted in the Hartland Shale from Kansas (Hattin, 1975; Riggs, 1944; Shimada and Nagrodski, 2010), very little is known about the vertebrate fauna in 

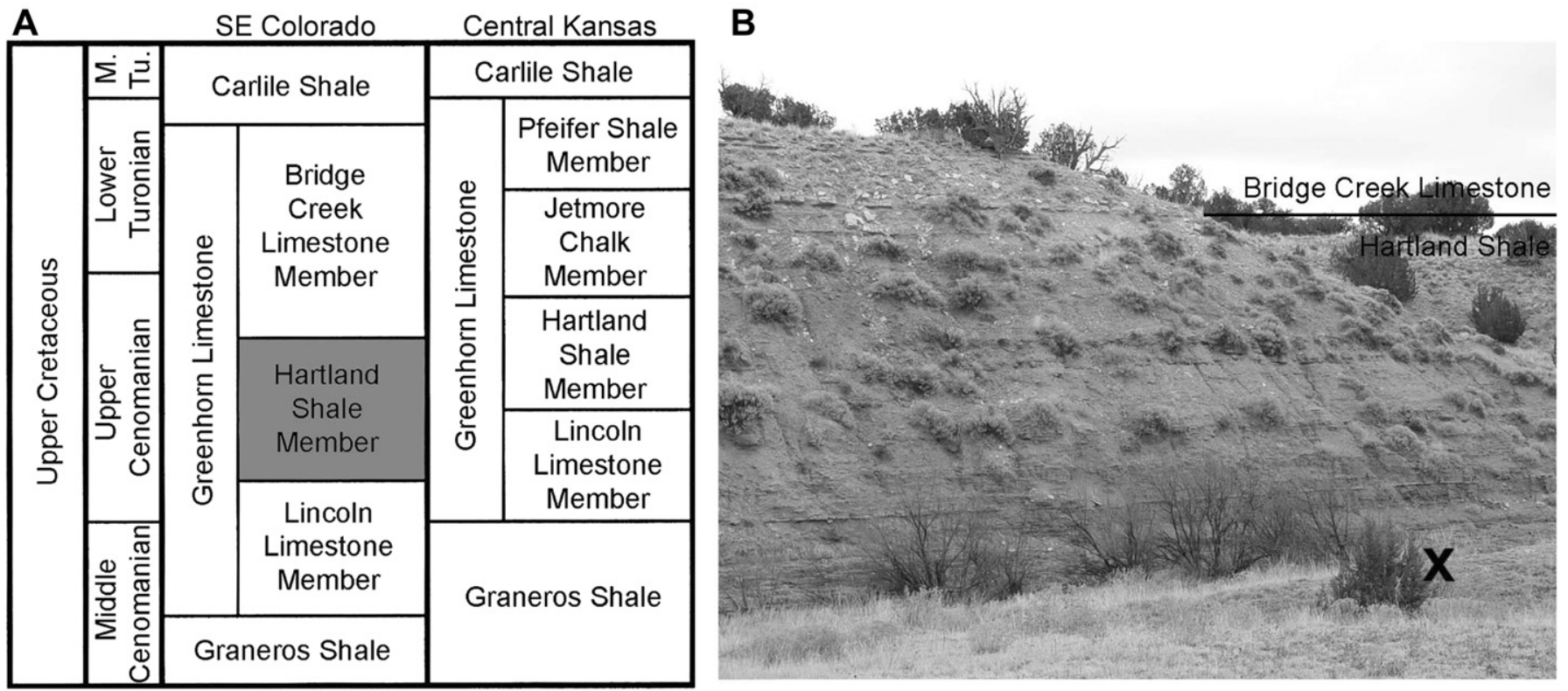

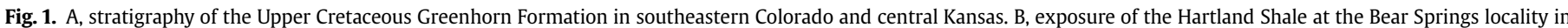

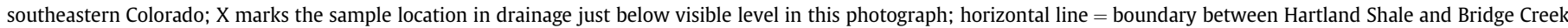
Limestone.

this portion of the Greenhorn Limestone. In 2006, one of us (BAS) discovered a Hartland Shale exposure ('Bear Springs locality'; Fig. 1B) on the Comanche National Grassland in southeastern Colorado that contains a thin fossiliferous, calcarenite bed. Samples of the deposit were sent to DePaul University, Chicago, Illinois, for examination of the composition of vertebrate remains. This study reports the findings, which provide further insight into the palaeoecology and evolution of the Western Interior Seaway.

\section{Stratigraphy and geological setting}

The Greenhorn Limestone disconformably overlies the Graneros Shale and underlies the Carlile Shale (Fig. 1A). In Colorado, it consists of three lithostratigraphic members. In ascending order, they are the Lincoln Limestone, Hartland Shale, and Bridge Creek Limestone (Kauffman, 1969) where their lithology reflects a transgressive event termed the Greenhorn Cyclothem (Kauffman, 1977). Deposition of the Bridge Creek Limestone marks the maximum transgressive phase of this cyclothem, where the water column in eastern Colorado is thought to have been greatest in the deepest part of the Western Interior Seaway, estimated maximum depths being $0.6-0.9 \mathrm{~km}$ (Eicher, 1967).

The fossiliferous calcarenite examined is located in the lower onethird of the Hartland Shale Member, roughly $4 \mathrm{~m}$ above the contact with the underlying Lincoln Limestone Member, although this measurement is approximated by correlation with nearby locations as the lower contact is not exposed at the Bear Springs locality. The calcarenite contains bivalve shells of taxonomically indeterminate inoceramids and the oyster Exogyra aff. E. boveyensis Bergquist, 1944 (Fig. 2A). Exogyra aff. E. boveyensis was initially reported to occur in the middle Late Cenomanian based on the fossil record in Kansas (Hattin, 1975), but Kauffman et al. (1993) depicted the occurrence of this taxon (also referred to as "Exogyra n. sp. aff. E. boveyensis") as restricted to their Calycoceras cantiaurinum ammonite zone, which is early Late Cenomanian in age. Kauffman et al. (1993, fig. 7) considered Exogyra aff. E. boveyensis to occur only in the upper one-third of the Lincoln Limestone. Given our occurrence datum, E. aff. E. boveyensis has either slightly greater stratigraphic range than shown or the boundary between the Lincoln Limestone and Hartland Shale needs to be lowered slightly to take into account this diachronous contact in southeastern Colorado. Regardless, the fossiliferous calcarenite bed examined in our study is interpreted to be early Late Cenomanian in age (ca. 94.6 Ma). Kauffman et al. (1993) radiometrically dated the C. cantiaurinum ammonite zone, which is immediately below the Dunveganoceras problematicum ammonite zone, to approximately $94.6 \mathrm{Ma}$. This agrees with the work of Cobban et al. (2006), which demonstrates that the $D$. problematicum ammonite zone is immediately above the $D$. pondi ammonite zone, dated as $94.71 \pm 0.49 \mathrm{Ma}$, but well below the next younger radiometrically-dated zone (Vascoceras diartianum ammonite zone), which is $93.99 \pm 0.72 \mathrm{Ma}$ and middle Late Cenomanian in age. As testament to this, a single specimen of Vascoceras sp. (FHSM IP-1476) was collected about $3.2 \mathrm{~km}$ from the Bear Springs locality within the lower portion of the Bridge Creek Limestone.

\section{Collecting method and specimen repository}

Rock samples containing noticeable fish remains (e.g., Fig. 2A) were collected directly from the rock exposure. Apart from one rock slab preserved for reference in an unaltered state, the sample slabs weighing approximately $2.3 \mathrm{~kg}$ (5 lbs) in total were submerged under household vinegar (i.e., 5\% acetic acid solution) to dissolve calcium carbonate (Fig. 2B). Two rock slabs were only partially dissolved, whereas the remaining sample was completely dissolved to extract undissolvable phosphatic fossil components. On average, 3.81 ( 1 gal) of vinegar was replaced every 10 days for about nine months. Disaggregated materials were rinsed with tap water, dried, and extracted using a dissecting microscope. All specimens are deposited in collections at Fort Hays State University's Sternberg Museum of Natural History (FHSM) in Hays, Kansas. The exact location of the Bear Springs locality is also on file at the museum.

\section{Systematic palaeontology}

Class Chondrichthyes

Subclass Elasmobranchii 

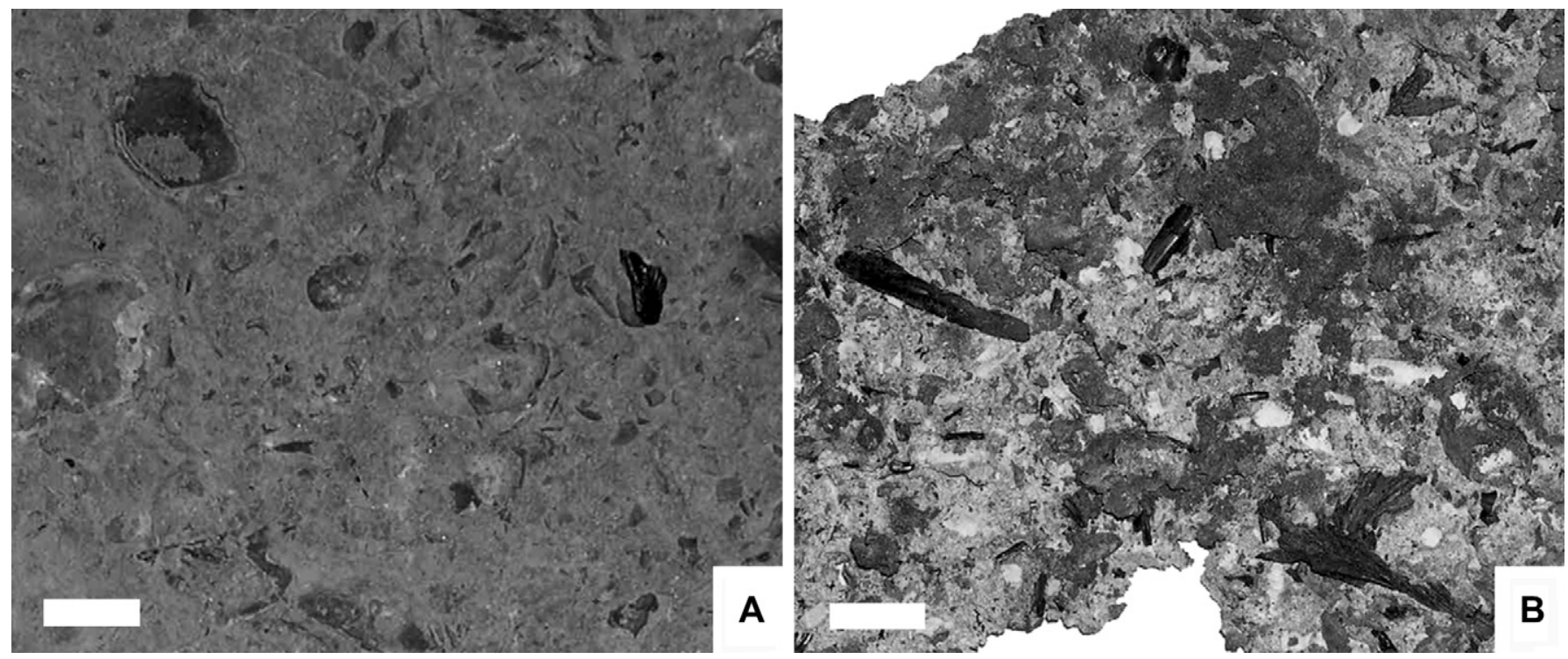

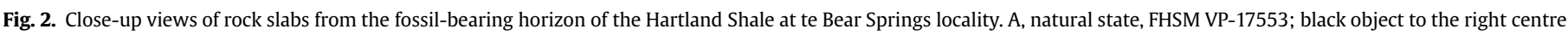

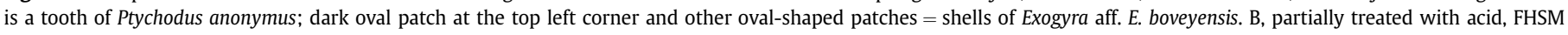
VP-17555; most black objects are bones and teeth of fishes. Scale bar represents $1 \mathrm{~cm}$.

Cohort Euselachii

Subcohort Neoselachii

Order Incertae sedis

Family Ptychodontidae Jaekel, 1898

Genus Ptychododus Agassiz, 1835

Ptychodus anonymus Williston, 1900a

Fig. 3A

Referred material. FHSM VP-17479, one tooth (Fig. 3A); FHSM VP-17480, 34 teeth.

Description. The tooth crown ranges up to $10 \mathrm{~mm}$ in width and $8 \mathrm{~mm}$ in height. Each tooth crown is broad and has a knob-like cusp with 8-12 transverse ridges. A marginal area surrounds the cusp and has a concentrically oriented, reticulated pattern. Each tooth has a low, box-like root that gives a total tooth height of $12.5 \mathrm{~mm}$ in the largest specimen (Fig. 3A).

Discussion. Whereas the first specimens of Ptychodus anonymus most likely occur in the lower Greenhorn Limestone ("Benton Formation" of Kansas in Williston, 1900a, b), this species is common in the Middle Cenomanian through Middle Turonian of the Western Interior Seaway deposits (see Shimada et al., 2006). The species is also known from the Upper Cenomanian in Bohemia, Czech Republic (Trbušek, 1999). Whereas teeth of $P$. anonymus have occasionally been misidentified as P. occidentalis (see Shimada et al., 2009), teeth from the Upper Coniacian and Lower Santonian of
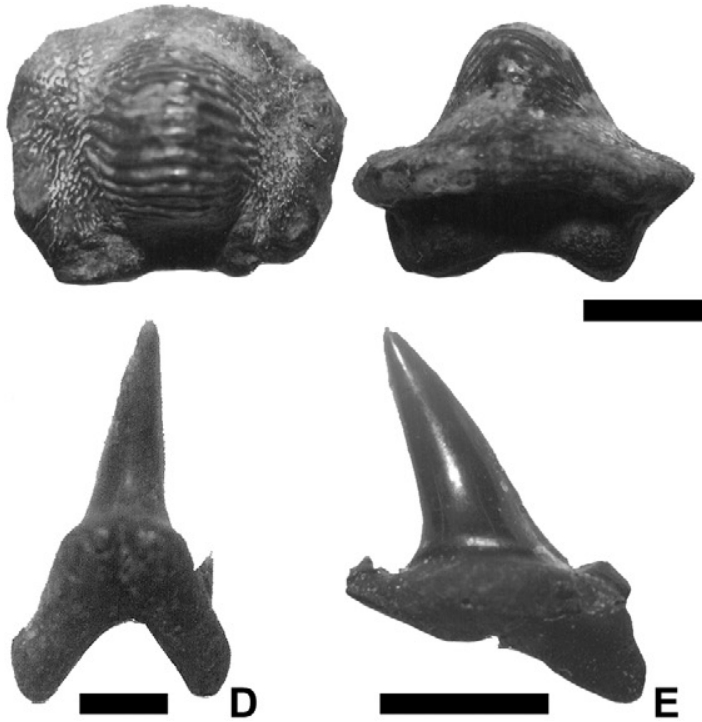

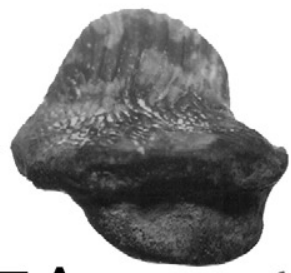

A

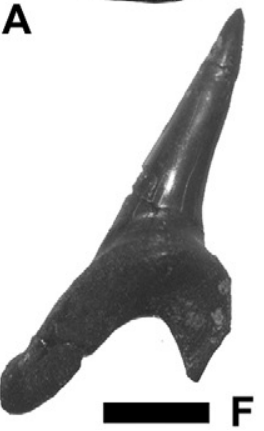

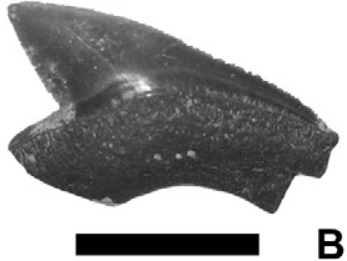

B

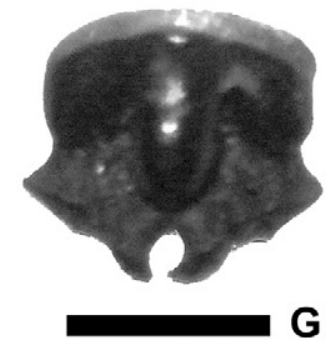

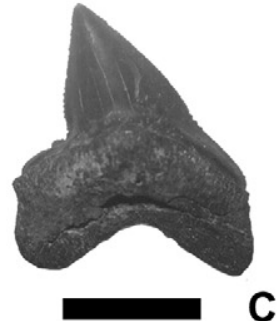

C

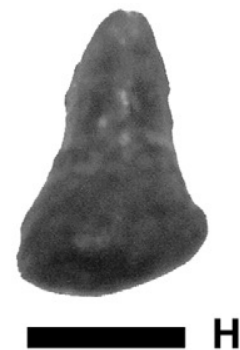

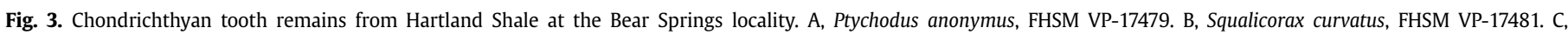

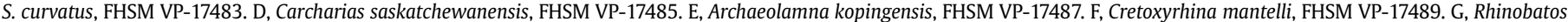

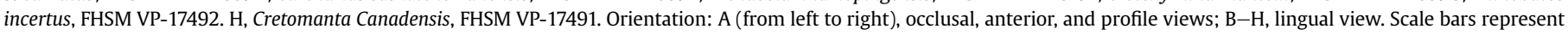
$5 \mathrm{~mm}$ in $\mathrm{A}-\mathrm{C}, \mathrm{E}, \mathrm{F}, 1 \mathrm{~mm}$ in $\mathrm{D}, 0.5 \mathrm{~mm}$ in $\mathrm{G}, \mathrm{H}$. 
North America (e.g., Niobrara Chalk of Kansas) that were traditionally referred to $P$. anonymus (e.g., see Shimada and Fielitz, 2006) have been reassigned to P. rugosus Dixon, 1850 (Hamm, 2010).

Order Lamniformes Berg, 1958

Family Anacoracidae Casier, 1947

Genus Squalicorax Whitley, 1939

Squalicorax curvatus (Williston, 1900a)

Fig. 3B, C

Referred material. FHSM VP-17481, one tooth (Fig. 3B); FHSM VP-17482, two teeth; FHSM VP-17483, one tooth (Fig. 3C); FHSM VP-17484, 16 teeth.

Description. Teeth of this taxon measure up to $11 \mathrm{~mm}$ in tooth height. They have a triangular, serrated crown that may be erect or steeply inclined distally. The mesial cutting edge is long and convex whereas the distal cutting edge is short and sometimes comes with a short distal heel. The lingual face is convex. The labial face is less convex than the lingual face but is commonly swollen slightly. There are two short, rounded root lobes with a low basal concavity between them. The root has a low lingual protuberance without any groove or nutritive foramina.

Discussion. Squalicorax baharijensis was synonymized with S. curvatus (Shimada et al., 2006); however, subsequent work (Siverson et al., 2007 ) suggests that $S$. curvatus may not be a valid taxon (a possible "nomen dubium"). Subsequently, it has been argued that S. curvatus should be retained as a valid species but that its relationship to $S$. baharijensis needs further examination, and that teeth referred to S. falcatus from Cenomanian deposits in the Western Interior may be better placed within S. curvatus (Underwood and Cumbaa, 2010). Whether or not those teeth are conspecific with S. falcatus from the post-Cenomanian deposits, including those from outside North America (e.g., Müller and Diedrich, 1991; Forey et al., 2003), remains unsubstantiated. We consider here that all of the Cenomanian teeth from the Western Interior previously referred to as S. falcatus belong to $S$. curvatus. However, we also note that there may still be at least one other Squalicorax species present in North America, such as Squalicorax sp. described by Shimada et al. (2006, fig. 8.10-8.13) and Shimada and Martin (2008, fig. 5D, E) that has teeth with finer serrations and deeper basal root concavity than $S$. curvatus. The presence of multiple Squalicorax species in the Cenomanian of North America is plausible given that multiple species of Squalicorax are known to occur in the Albian (Siverson et al., 2007) and postCenomanian deposits (Shimada and Fielitz, 2006; Shimada, 2008). Regardless, our taxonomic treatments of Squalicorax taxa and that of others (Underwood and Cumbaa, 2010) have made S. curvatus the most common Squalicorax species in the mid-Cenomanian of North America.

Family ‘Odontaspididae’ Muller and Henle, 1839

Genus Carcharias Rafinesque, 1810

Carcharias saskatchewanensis (Case, Tokaryk, and Baird, 1990) Fig. 3D

Referred material. FHSM VP-17485, one tooth (Fig. 3D); FHSM VP-17486, 23 teeth.

Description. Teeth of this taxon measure no more than $5 \mathrm{~mm}$ in total tooth height. Each tooth has a triangular main cusp, one pair of lateral cusplets, and a bilobed root. The main cusp measures up to $4 \mathrm{~mm}$ high and $2.5 \mathrm{~mm}$ in basal width, and has distinct mesial and distal cutting edges. The crown face is generally smooth but one or two short vertical ridges may occur near the crown base on the labial side. The lateral cusplets are tall and narrow, and are well separated from the main cusp. The tooth neck on the lingual face is narrow but distinct. The root generally has a tight basal concavity and a strong lingual protuberance with a shallow nutritive groove.

Discussion. This taxon is relatively common in the Cenomanian deposits of the North American Western Interior. It is reported from Saskatchewan, Canada (Case et al., 1990; for stratigraphic discussion of the type locality, see Cumbaa and Tokaryk, 1999) as well as from South Dakota, Kansas, Colorado, and Texas (see Shimada et al., 2006). Teeth of this species are similar in size and shape to those of Eostriatolamia tenuiplicatus (Cappetta and Case, 1975), which is common in the Cenomanian of Kansas and Colorado (Shimada et al., 2006; Shimada and Martin, 2008). However, C. saskatchewanensis has a more robust crown than E. tenuiplicatus and exhibits smoother surfaces, the latter being characterized by prominent vertical ridges along the crown base.

Family Archaeolamnidae Underwood and Cumbaa, 2010 Genus Archaeolamna Siverson, 1992

Archaeolamna kopingensis (Davis, 1890)

Fig. 3E

Referred material. FHSM VP-17487, one tooth (Fig. 3E); FHSM VP-17488 three teeth.

Description. Teeth of Archaeolamna kopingensis measure up to $13 \mathrm{~mm}$ in total height. They consist of a large triangular main cusp with one pair of prominent triangular lateral cusplets. The root is bilobed. It has a moderately wide basal concavity and generally possesses one nutritive foramen on a moderately raised lingual protuberance. Teeth of $A$. kopingensis are similar to teeth of Cretoxyrhina mantelli (see below) but with a less robust crown and more prominent lateral cusplets.

Discussion. Teeth of Archaeolamna kopingensis and closely related species are known from the Albian-Maastrichtian worldwide (see Cook et al., 2011, and references therein). The species has been known for over a century, but its generic and familial assignments were unstable until the genus Archaeolamna Siverson, 1992, and the family Archaeolamnidae Underwood and Cumbaa, 2010, were established. Furthermore, the range of variation in tooth morphology and the pattern of dentition within the species are now clearly based on an articulated dentition from the Pierre Shale of Kansas (Cook et al., 2011). This study also indicates that the shark possibly reached $3-4 \mathrm{~m}$ in total length and probably fed on large prey.

Family Cretoxyrhinidae Glickman, 1958

Genus Cretoxyrhina Glickman, 1958

Cretoxyrhina mantelli (Agassiz, 1843)

Fig. 3F

Referred material. FHSM VP-17489, one tooth (Fig. 3F); FHSM VP-17490, three teeth.

Description. Teeth of this species from the Bear Springs locality measure up to $23 \mathrm{~mm}$ in total height. Typically, each tooth has a robust, smooth-surfaced, triangular crown with sharp cutting edges and a bilobed root with a prominent lingual protuberance and a moderate to high basal concavity. The protuberance usually has a pit-like nutritive foramen. Lateral teeth are unusually small 
and possess a distally inclined, broad crown, a moderately broad basal concavity, and possibly a pair of minute lateral cusplets.

Discussion. Cretoxyrhina mantelli is known from the CenomanianCampanian rocks nearly worldwide, including various Cenomanian deposits of the North American Western Interior Sea (Shimada et al., 2006). Recent work suggests that $C$. denticulata as erected by Glickman (1957) is valid and that additional material exists from a Cenomanian deposit in Saskatchewan, Canada (Underwood and Cumbaa, 2010). Here, we question the validity of $C$. denticulata, considering it to be synonymous with $C$. mantelli as did Siverson (1996). First, Underwood and Cumbaa (2010, p. 912) stated that the "teeth of this taxon [C. denticulata] appear to largely represent juveniles" that exhibit lateral cusplets, which is a main morphologic feature of the species that separates it from $C$. mantelli in addition to its restricted stratigraphic occurrence in the Cenomanian. They also noted that "the largest tooth here lacks lateral cusplets which are present in smaller teeth from similar jaw positions" (p. 912). We note that some extant lamniforms without lateral cusplets as adults commonly exhibit lateral cusplets as subadults (embryonic and juvenile stage), including anterior teeth (e.g., Francis, 1996; Shimada, 2002). We agree with Underwood and Cumbaa (2010, p. 213) that "teeth from almost all jaw positions of juveniles" of the Cenomanian form they described as C. denticulata "had lateral cusplets, which are retained in lateral ... teeth of adults." However, the occurrence of lateral cusplets is not uncommon in lateral teeth of $C$. mantelli even in post-Cenomanian specimens (e.g., FHSM VP-2187 described by Shimada, 1997). Thus, the presence or absence of lateral cusplets and the chronological division (Cenomanian vs. post-Cenomanian) are arguably an insufficient basis on which to separate $C$. denticulata from $C$. mantelli.

Order Rajiformes Berg, 1940

Family Rhinobatidae Muller and Henle, 1838

Genus Rhinobatos Linck, 1790

\section{Rhinobatos incertus}

Fig. 3G

Referred material. FHSM VP-17492, one tooth (Fig. 3G); FHSM VP-17493, three teeth.

Description. Teeth of Rhinobatos incertus measure up to about $1 \mathrm{~mm}$ in total height and consist of a massive crown and a bilobed root. The crown is mesiodistally broad and low, and its crown may be pointed or rounded. The labial surface of the crown is featureless and has a rounded base that overhangs the root. The lingual surface of the crown is divided by two deep grooves defining three (mesial, distal, and medial) rounded protuberances. The root is directed lingually and is constricted near the crown and laterally broad near the middle. The two lobes of the root are divided by a tight, small, semicircular basal concavity.

Discussion. The genus Rhinobatos (guitarfish) occurs nearly worldwide from the Lower Barremian (Biddle and Landemaine, 1988) through to the Recent (Herman et al., 1997). Recent studies (e.g., Everhart, 2007b; Cumbaa et al., 2010) have shown that Rhinobatos teeth are quite common throughout Late Cretaceous rocks in North America. Like extant Rhinobatos (e.g., Başusta et al., 2007; Ismen et al., 2007), small crushing-type teeth of fossil Rhinobatos species indicate that extinct forms were probably also benthic and fed primarily on crustaceans and small bony fishes.

Order Incertae sedis

Family Incertae sedis

Genus Cretomanta Case, Tokaryk, and Baird, 1990
Cretomanta canadensis Case, Tokaryk, and Baird, 1990

Fig. $3 \mathrm{H}$

Referred material. FHSM VP-17491, one tooth (Fig. 3H).

Description. The tooth of Cretomanta canadensis is small, measuring about $1 \mathrm{~mm}$ in total height. It has a hook-shaped conical crown with a massive globular root. The crown shows a strong lingual curve and has blunt cutting edges near the crown apex. The crown base is slightly constricted, but there is no tooth neck between the crown and the root. The entire lingual face of the root forms a protuberance with no nutritive groove or pore.

Discussion. This taxon has been reported from CenomanianTuronian rocks of Saskatchewan, Kansas, Colorado, South Dakota, and Texas (see Shimada et al., 2006; Cumbaa et al., 2010). Its taxonomic affinity remains unresolved. Case et al. (1990) suggested that it belongs to Mobulidae Gill, 1893 (manta ray), whereas Welton and Farish (1993) classified it in Rhincodontidae Garman, 1913 (whale shark). This taxon is rare at the Bear Springs locality.

Class Osteichthyes

Subclass Actinopterygii

Superorder Neopterygii

Order Pycnodontiformes Berg, 1940

Family Pycnodontidae Agassiz, 1833

Genus Micropycnodon Hibbard and Graffham, 1945

Micropycnodon kansasensis (Hibbard and Graffham, 1941) Fig. $4 \mathrm{~A}$

Referred material. FHSM VP-17495, one tooth (Fig. 4A); FHSM VP-17496, one tooth; FHSM VP-17497, one tooth.

Description. Teeth of this taxon in the sample measure up to about $1 \mathrm{~mm}$ in maximum dimension and are represented by molariform (FHSM VP-17495 and VP-17496) and incisiform (FHSM VP-17497) teeth. The molariform teeth are represented only by the domeshaped crown where multiple blunt tubercles are present on the occlusal surface (Fig. 4A). The incisiform tooth (not figured) is missing much of the crown but is characterized by an occlusobasally elongate, columnar root.

Discussion. Micropycnodon kansasensis was first described from the Niobrara Chalk of Kansas (see Shimada and Fielitz, 2006). It is now reported from the mid-Cenomanian marine deposits in Colorado and Kansas as well as in Saskatchewan, Canada (see Cumbaa et al., 2010), giving it a total stratigraphic range of Cenomanian-Santonian (Everhart, 2007a). It was a small durophagous fish that probably measured less than $30 \mathrm{~cm}$ in length (Everhart, 2007a). It also served as food for other animals, as evidenced by a report (Everhart, 2007a) on a coprolite from the Niobrara Chalk of Kansas that contains remains of $M$. kansasensis in it.

Family Nursallidae Blot, 1987

Genus Palaeobalistum Blainville, 1818

cf. Palaeobalistum sp.

Fig. 4B

Referred material. FHSM VP-17498, one tooth (Fig. 4B); FHSM VP-17499, one tooth; FHSM VP-17500, three teeth. 

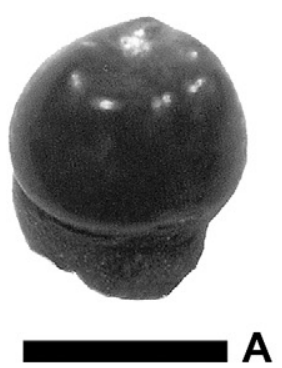

\begin{abstract}
A
\end{abstract}
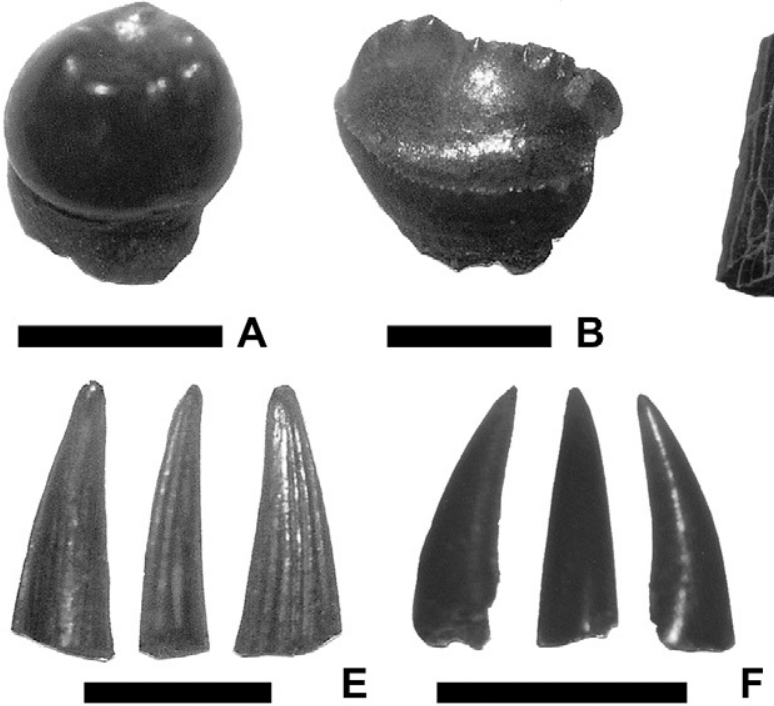
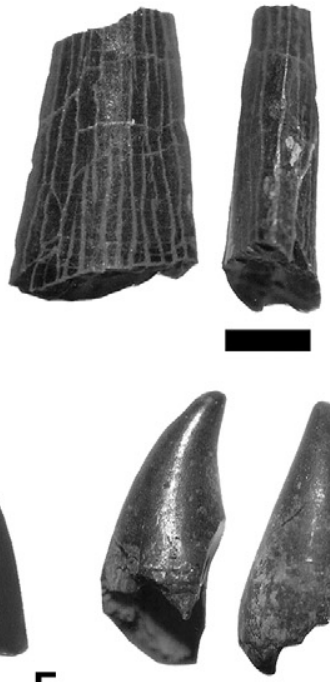

$\mathbf{F}$
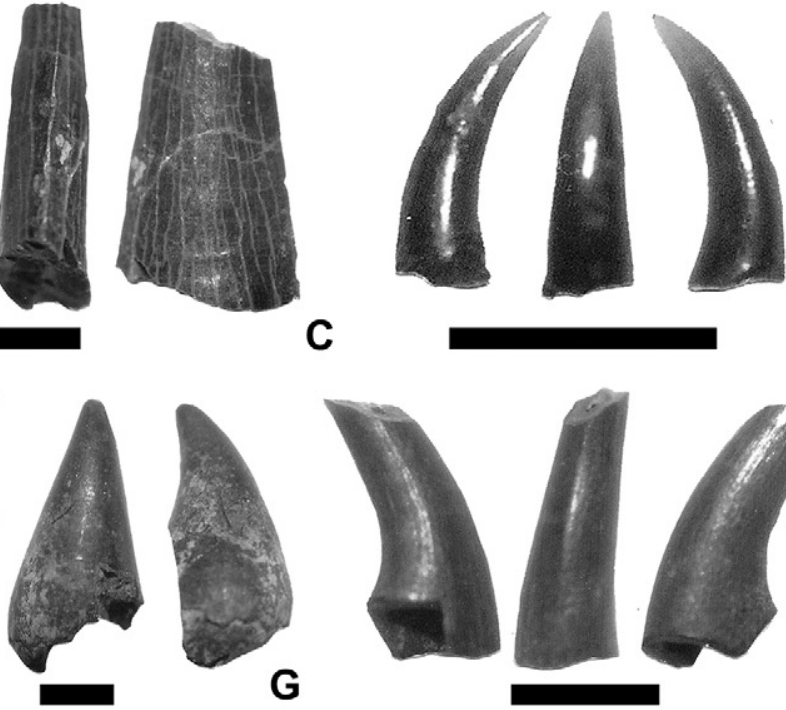

C

D
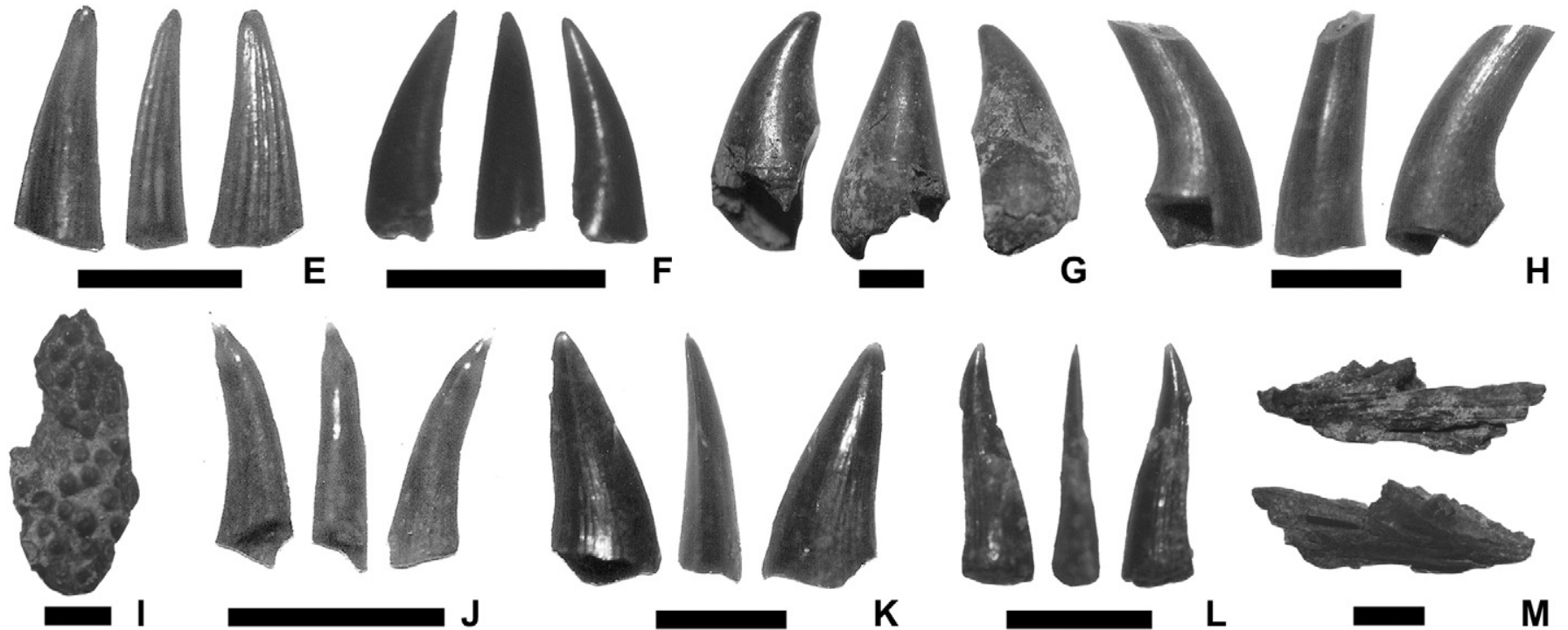

H
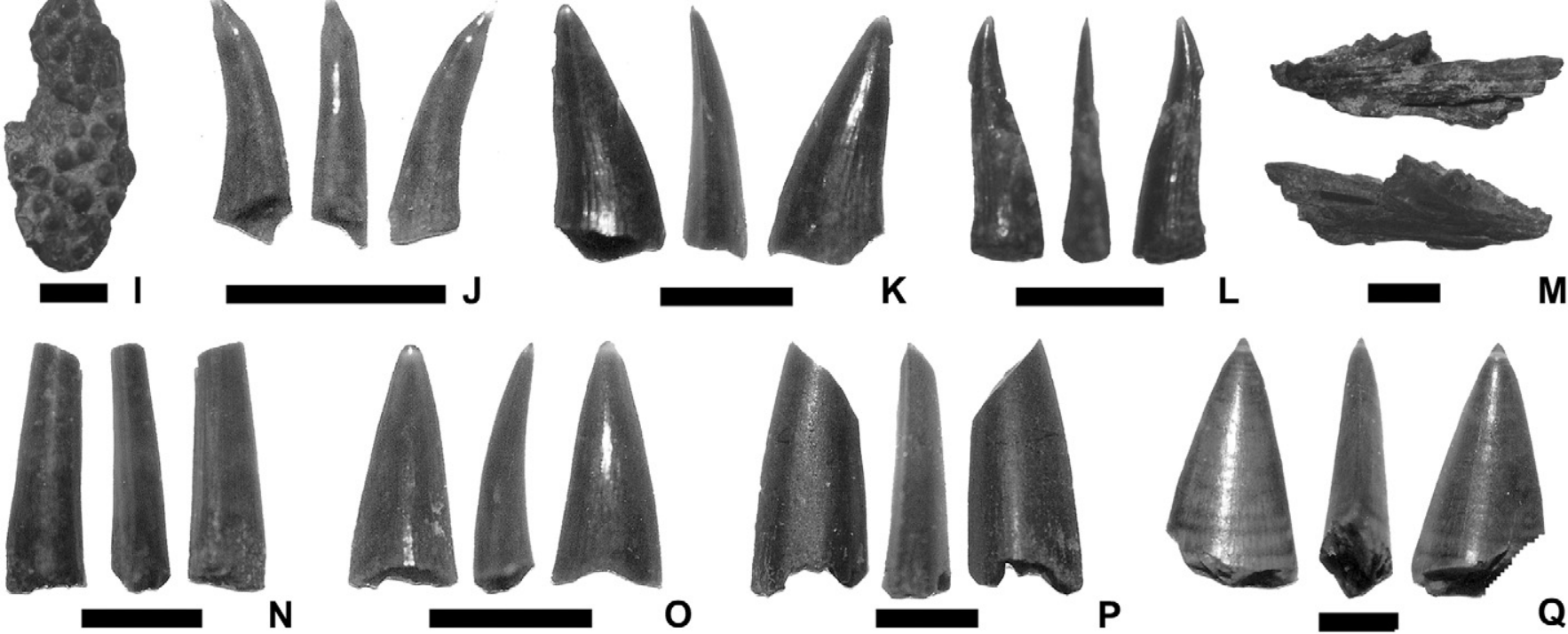

$\mathbf{L}$

$\mathbf{M}$
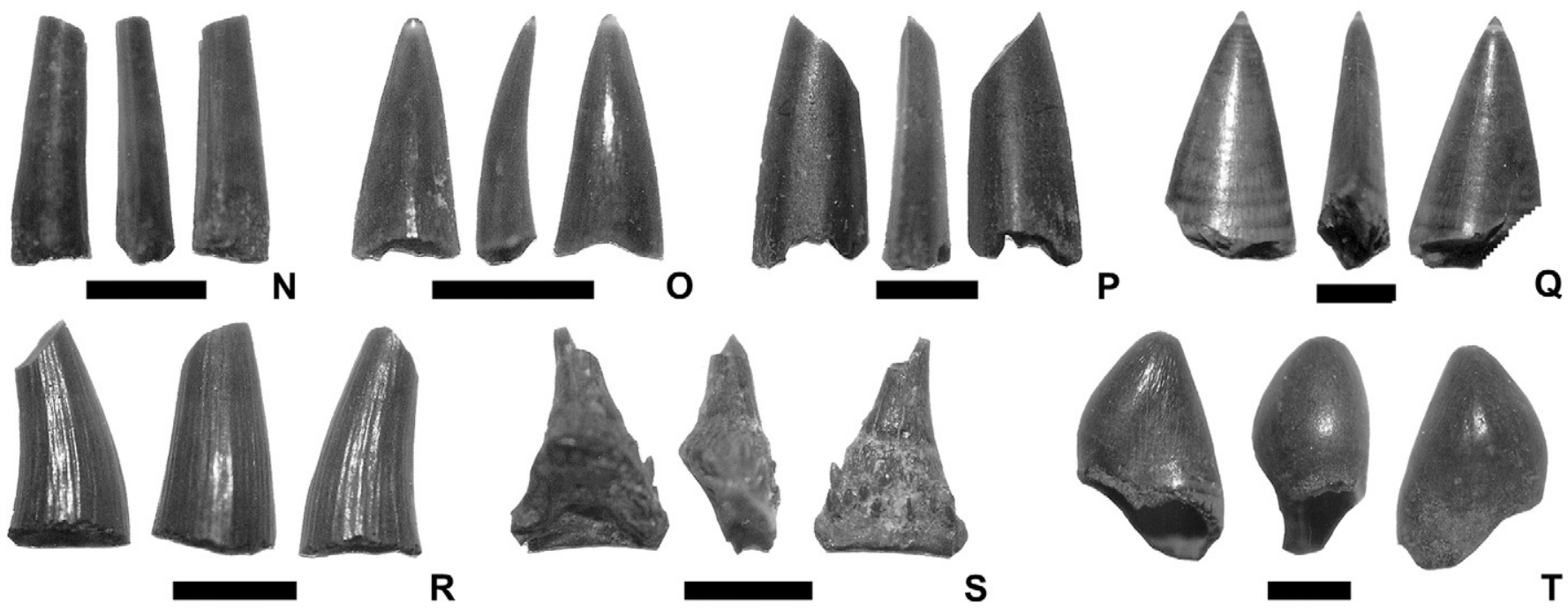

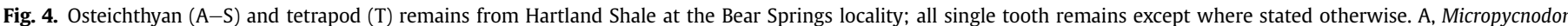

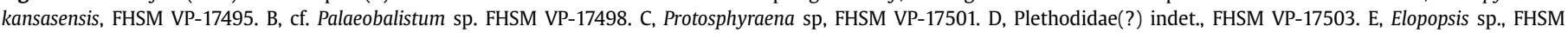

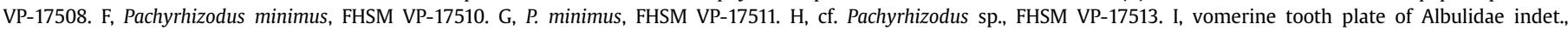

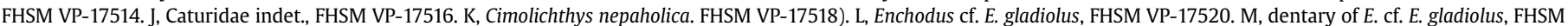

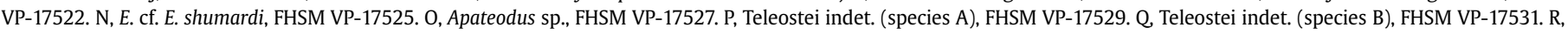

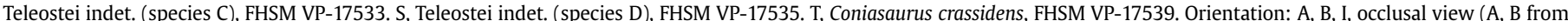

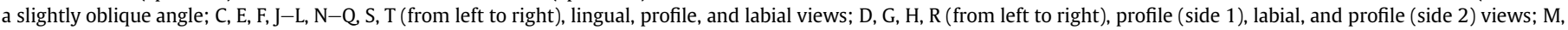
lingual (top) and labial (bottom) views. Scale bars represent $1 \mathrm{~mm}$ in A-L, N-T, $5 \mathrm{~mm}$ in $\mathrm{M}$.

Description. Teeth of this taxon usually measure between 1 and $2 \mathrm{~mm}$ in maximum dimension. Their outline in occlusobasal view is oval to triangular, and some are elongated. One side of the crown is usually raised to form a ridge, whereas the rest of the occlusal surface is flat and slants. The root is short and slightly narrower basally. A large pulp cavity forms at the centre of the root.
Discussion. Palaeobalistum was previously known primarily from outside North America, such as the Cenomanian-Turonian of Morocco and the Eocene of Italy (Arambourg, 1954; Maisey, 2000; Poyato-Ariza and Wenz, 2002). In recent years, it has been found to be common in the Upper Cretaceous at other localities. North American examples include the Middle Cenomanian of 
Saskatchewan and Colorado (Cumbaa et al., 2010), the Santonian(?) of Kansas (Shimada and Fielitz, 2006), and the Lower Campanian of New Jersey (Robb, 2004; see Shimada et al., 2006).

Order Amiiformes Hay, 1929

Family Caturidae Owen, 1860

Caturidae indet.

Fig. 4J

Referred material. FHSM VP-17516, one tooth (Fig. 4J); FHSM VP-17517, one tooth.

Description. Teeth from this taxon are conical and measure up to $2 \mathrm{~mm}$ in height. One of the specimens exhibits a transparent enamaloid cap on the tooth tip that extends nearly half-way down the tooth (FHSM VP-17517). The teeth also exhibit a slight lingual curve.

Discussion. Caturids are extinct amiiforms with a long stratigraphic range that extends from the Lower Jurassic to the Upper Cretaceous (Grande and Bemis, 1998; Cumbaa et al., 2006). Caturid remains are generally rare in North American deposits, but they are known from the Cenomanian-Turonian of Canada (Cumbaa et al., 2006, 2010) and the Cenomanian of Kansas (Shimada and Martin, 2008). Teeth of this taxon are relatively rare at the Bear Springs locality.

Subdivision Teleostei

Order Pachycormiformes Berg, 1940

Family Pachycormidae Woodward, 1895

Genus Protosphyraena Leidy, 1857a

\section{Protosphyraena sp.}

Fig. 4C

Referred material. FHSM VP-17501, one tooth (Fig. 4C); FHSM VP-17502, five teeth.

Description. Teeth of this taxon measure up to about $10 \mathrm{~mm}$ in height. They are triangular and possess well-defined mesial and distal cutting edges. Both lingual and labial faces are rounded and exhibit fine vertical striations.

Discussion. Protosphyraena is an extinct bony fish taxon that resembled a modern swordfish, which is characterized by an elongate rostrum with an elongate body and a large symmetrical lunate caudal fin. It is known from Late Cretaceous deposits in various parts of the world (e.g., Woodward, 1908; Leriche, 1929; Bardack, 1968; Applegate, 1970; Stewart, 1988; Diedrich, 2001; Vullo et al., 2009). In North America, the oldest species of Protosphyraena is $P$. bentoniana Stewart, 1898 , from the mid-Cenomanian (Lincoln Limestone) in central Kansas. However, the type specimen of this species does not preserve teeth; thus, it is not possible to determine whether or not teeth of Protosphyraena from the Bear Springs locality belong to $P$. bentoniana.

Order Tselfatiiformes Nelson, 1994

Family Plethodidae Loomis, 1900

Plethodidae(?) indet.

Fig. 4D

Referred material. FHSM VP-17503, one tooth (Fig. 4D); FHSM VP-17504, one tooth; FHSM VP-17505, five teeth; FHSM VP-17506, one bone; FHSM VP-17507, five bones.
Description. Teeth of this taxon are hook-shaped and measure up to $2 \mathrm{~mm}$. The crown base is nearly circular. They are similar to teeth of Pachyrhizodus minimus (see below) but differ from them by exhibiting a more pronounced lingual curvature. Bones of this taxon are characterized by having coarsely distributed pit-like depressions on their exterior surface, much like the texture of plethodid bones depicted by Loomis (1900, pl. 22).

Discussion. Plethodids are known worldwide from AlbianCampanian marine deposits (e.g., Applegate, 1970; Chalifa and Lewy, 1991; Patterson, 1993; Chanet, 1997; Martin et al., 1998; Fielitz and Shimada, 1999; Shimada and Fielitz, 2006). Undisputed plethodids occur in the lower Greenhorn Limestone of North America; these are the oldest materials from the continent (e.g., Witzke, 1981; Shimada and Schumacher, 2003; cf. Shimada et al., 2006; Shimada and Martin, 2008). However, because the morphological variation of plethodid teeth is not well studied and bone texture is not diagnostic below family level, species identifications cannot be made for plethodid material from the Bear Springs locality.

Order Elopiformes Greenwood, Rosen, Weitzman, and Meyers, 1966 Family Pachyrhizodontidae Cope, 1872b

Genus Elopopsis Heckel, 1856

Elopopsis sp.

Fig. 4E

Referred material. FHSM VP-17508, one tooth (Fig. 4E); FHSM VP-17509, 21 teeth.

Description. Teeth of this taxon measure up to $4 \mathrm{~mm}$ in tooth height. They are overall triangular and exhibit prominent longitudinal grooves that extend from the tooth tip to the tooth base. Some of them have a translucent enamaloid cap on the tooth tip.

Discussion. Cumbaa et al. (2006) reported teeth of Elopopsis from the mid-Cenomanian of Saskatchewan, Canada (see also Cumbaa et al., 2010). Elsewhere, Elopopsis is known from the Cenomanian of Jugoslavia, Czechoslovakia and Morocco, the Turonian of England, and the Campanian of Westphalia (Woodward, 1908; Arambourg, 1954; Forey, 1977). Although the post-cranial anatomy of Elopopsis is poorly known, the taxon probably did not exceed $1 \mathrm{~m}$ in length, judging from the size of the skull (see Forey, 1977, fig. 35).

Genus Pachyrhizodus Dixon, 1850

Pachyrhizodus minimus Stewart, 1899

Fig. 4F, G

Referred material. FHSM VP-17510, one tooth (Fig. 4F); FHSM VP-17511, one tooth (Fig. 4G); FHSM VP-17512, 1502 teeth.

Description. Teeth of this species measure up to $4.5 \mathrm{~mm}$ in height. They consist of a lingually curved, smooth, conical crown. The basin-shaped crown base is filled with dentine and shows no recognizable pulp cavity.

Discussion. The genus Pachyrhizodus is known from the Albian of Australia (Bardack, 1962; Bartholomai, 1969) as well as from various Late Cretaceous deposits in Europe and North America (e.g., Stewart, 1898, 1899, 1900; Loomis, 1900; Applegate, 1970; Forey, 1977; Wiffen, 1983; Longbottom and Patterson, 2002). The North American material is represented by four species: P. caninus 
Cope, 1872b, P. kingi Cope, 1872b, P. leptopsis Cope, 1874, and P. minimus Stewart 1899 (Shimada and Fielitz, 2006), where P. kingi and $P$. leptopsis may be synonyms of $P$. caninus (see Applegate, 1970; Forey, 1977). Pachyrhizodus minimus ranges stratigraphically from the mid-Cenomanian to at least the mid-Campanian (e.g., Cumbaa et al., 2010; Carpenter, 2003), and is the smallest North American species of the genus, measuring up to about $80 \mathrm{~cm}$ in length (e.g., see Applegate, 1970, fig. 189). Teeth of $P$. minimus are the second most common vertebrate remains at the Bear Springs locality next to teeth of Enchodus cf. E. gladiolus (Table 1).

\section{cf. Pachyrhizodus sp.}

Fig. $4 \mathrm{H}$

Referred material. FHSM VP-17513, one tooth (Fig. 4H).

Description. The tooth measures up to about $2.5 \mathrm{~mm}$ in height. It is characterized by a finely striated, conical crown, which has a gentle lingual curvature. The tooth base shows a large pulp cavity. It is more robust and elongate than the tooth of $P$. minimus.

Discussion. The exact taxonomic identity of this tooth is uncertain, but it is referred to as cf. Pachyrhizodus sp. because of its large, curved, conical shape. The same tooth form also occurs in the Lincoln Limestone of Kansas and Colorado (Shimada et al., 2006; Shimada and Martin, 2008). If it indeed belongs to Pachyrhizodus, the form is clearly from a species larger than P. minimus, where the largest Pachyrhizodus reached about $2 \mathrm{~m}$ in total length (Stewart and Bell, 1994).

\section{Table 1}

Vertebrate taxa (with their sample sizes) from Hartland Shale at the Bear Springs locality (BS: this study) in southeastern Colorado compared with fauna from the basal Lincoln Limestone in central Kansas (KS: Liggett et al., 2005; Shimada and Martin, 2008) and southeastern Colorado (CO: Shimada et al., 2006). Symbols: X, present; -, absent; NA, not applicable.

\begin{tabular}{|c|c|c|c|}
\hline $\begin{array}{l}\text { Higher category } \\
\text { Taxon }\end{array}$ & Sample size (BS) & KS & $\mathrm{CO}$ \\
\hline \multicolumn{4}{|l|}{ Chondrichthyes } \\
\hline Ptychodus anonymus & 35 teeth & $\mathrm{X}$ & $\mathrm{X}$ \\
\hline Squalicorax curvatus & 20 teeth & $\mathrm{X}$ & $\mathrm{X}$ \\
\hline Carcharias saskatchewanensis & 24 teeth & $\mathrm{X}$ & $\mathrm{X}$ \\
\hline Archaeolamna kopingensis & 4 teeth & $\mathrm{X}$ & $\mathrm{X}$ \\
\hline Cretoxyrhina mantelli & 4 teeth & $\mathrm{X}$ & $\mathrm{X}$ \\
\hline Cretomanta canadensis & 1 tooth & $\mathrm{X}$ & $\mathrm{X}$ \\
\hline Rhinobatos incertus & 4 teeth & $\mathrm{X}$ & $\mathrm{X}$ \\
\hline Chondrichthyes indet. & 1 vertebra & NA & NA \\
\hline \multicolumn{4}{|l|}{ Osteichthyes } \\
\hline Micropycnodon kansasensis & 3 teeth & $\mathrm{X}$ & $\mathrm{X}$ \\
\hline Palaeobalistum sp. & 5 teeth & - & $\mathrm{X}$ \\
\hline Caturidae indet. & 2 teeth & $\mathrm{X}$ & - \\
\hline Protosphyraena sp. & 6 teeth & $\mathrm{X}$ & $\mathrm{X}$ \\
\hline Plethodidae indet. & 7 teeth, 6 bones & $\mathrm{X}$ & $\mathrm{X}$ \\
\hline Elopopsis sp. & 22 teeth & - & - \\
\hline Pachyrhizodus minimus & 1504 teeth & $\mathrm{X}$ & $\mathrm{X}$ \\
\hline cf. Pachyrhizodus sp. & 1 tooth & $\mathrm{X}$ & $\mathrm{X}$ \\
\hline Albulidae indet. & 1 tooth plate, 4 pieces & $\mathrm{X}$ & $\mathrm{X}$ \\
\hline Cimolichthys nepaholica & 8 teeth & - & - \\
\hline Enchodus cf. E. gladiolus & 3489 teeth, 1 jaw bone & $\mathrm{X}$ & $\mathrm{X}$ \\
\hline Enchodus cf. E. shumardi & 12 teeth & $\mathrm{X}$ & $\mathrm{X}$ \\
\hline Apateodus sp. & 3 teeth & - & - \\
\hline Teleostei indet. (sp. A) & 8 teeth & $\mathrm{X}$ & $\mathrm{X}$ \\
\hline Teleostei indet. (sp. B) & 17 teeth & $\mathrm{X}$ & $\mathrm{X}$ \\
\hline Teleostei indet. (sp. C) & 11 teeth & $\mathrm{X}$ & $\mathrm{X}$ \\
\hline Teleostei indet. (sp. D) & 2 teeth & - & - \\
\hline Teleostei indet. & 1 jaw bone & NA & NA \\
\hline Osteichthyes indet. & 18 vertebrae & NA & NA \\
\hline \multicolumn{4}{|l|}{ Reptilia } \\
\hline Coniasaurus crassidens & 18 teeth & $\mathrm{X}$ & $\mathrm{X}$ \\
\hline \multicolumn{4}{|l|}{ Miscellaneous } \\
\hline Vertebrata indet. & ca. 10,000 bone fragments & NA & NA \\
\hline Vertebrata(?) indet. & 35 pebbles & NA & NA \\
\hline
\end{tabular}

Order Albuliformes Forey, Littlewood, Ritchie, and Meyer, 1996 Suborder Albuloidei Greenwood, Rosen, Weitzman, and Meyers, 1966

Family Albulidae Bleeker, 1859

Albulidae indet.

Fig. 4I

Referred material. FHSM VP-17514, one tooth plate (Fig. 4I); FHSM VP-17515, eight skeletal and dental pieces.

Description. Specimens of albulid dental plates have many tightlypacked, small, dome-shaped teeth that measure roughly $0.2 \mathrm{~mm}$ in diameter (FHSM VP-17514). Each dome-shaped tooth is rootless, and a thin layer of enameloid covers the massive dentine that bears a depression-like pulp cavity at the centre of its base.

Discussion. Albulid fishes have a long stratigraphic range, extending from the Cenomanian through Recent with worldwide occurrences (e.g., see Shimada et al., 2006). They possess parasphenoid and basibranchial tooth plates (e.g., Applegate, 1970, fig. 195; Gallo and de Figueiredo, 2002). Isolated teeth and tooth plates of albulids are relatively common in the fossil record (e.g., Shimada et al., 2006; Shimada and Martin, 2008; Vullo et al., 2009), but specific taxonomic identifications of such isolated materials are practically impossible.

Order Aulopiformes Rosen, 1973

Suborder Enchodontoidei sensu Nelson, 1994

Superfamily Cimolichthyoidea Nelson, 1994

Family Cimolichthyidae Goody, 1969

Genus Cimolichthys Leidy, 1857a

Cimolichthys nepaholica (Cope, 1872a)

Fig. $4 \mathrm{~K}$

Referred material. FHSM VP-17518, one tooth (Fig. 4K); FHSM VP-17519, seven teeth.

Description. The teeth of this taxon can measure up to about $3.5 \mathrm{~mm}$ in height. Vertical ridges are present in the teeth that stretch from the tooth tip down to the base of the tooth. These teeth have a transparent enamaloid cap on the tooth tip. The teeth are generally triangular in shape with cutting edges and are slightly curved lingually.

Discussion. Cimolichthys nepaholica is a relatively common fish in Coniacian-Campanian marine deposits of North America, including Manitoba, Wyoming, South Dakota, Kansas, and Alabama (Russell, 1988; Martin et al., 1998). The Cenomanian specimens of C. nepaholica described here are important because they represent the oldest record of the genus Cimolichthys, where the previously records came from the Turonian of England and Canada (Woodward, 1902; Fielitz, 1996). On the basis of skeletal anatomy, Goody (1970) considered Cimolichthys to be a fast, active predator. This contention has now been supported by Cimolichthys specimens with stomach contents that include "a large Enchodus" and an unidentified fish (Everhart 2005, p. 87) as well as squid (Stewart and Carpenter, 1990).

Family Enchodontidae Woodward, 1901

Genus Enchodus Agassiz, 1835

Enchodus cf. E. gladiolus (Cope, 1872b)

Fig. 4L, M 
Referred material. FHSM VP-17520, one tooth (Fig. 4L); FHSM VP-17521, one tooth; FHSM VP-17522, one dentary bone (Fig. 4M); FHSM VP-17523, 3470 teeth; FHSM VP-17524, 17 teeth.

Description. Teeth of Enchodus cf. E. gladiolus from the Bear Springs locality measure up to about $5.5 \mathrm{~mm}$ in height. They are slender where the lingual face is more convex than the labial face. Both lingual and labial faces generally exhibit striations. Although the teeth are generally curved distally, the tooth tip may exhibit a mesial flexure. They have unserrated cutting edges in which the distal cutting edge is not quite as well defined as the mesial one. One dentary bone recovered from the Bear Springs locality (Fig. 4M) measures about $19.5 \mathrm{~mm}$ in maximum preserved length and bears the base of one large tooth and several small marginal teeth.

Discussion. A recent review of North American species of Enchodus (Parris et al., 2007) has shown that there are five valid species of the genus in North America: E. dirus (Leidy, 1857b), E. ferox Leidy, 1855, E. gladiolus, E. petrosus Cope, 1874, and E. shumardi Leidy, 1856 (cf. Goody, 1976; Fielitz, 2004). Our identification is based on an identical morphological range seen in teeth identified as E. cf. E. gladiolus. Like the basal Lincoln Limestone in Kansas and Colorado (Shimada et al., 2006; Shimada and Martin, 2008), isolated teeth of Enchodus cf. E. gladiolus are the most common vertebrate remains in the Bear Springs locality. Whether or not this mid-Cenomanian form is conspecific with $E$. gladiolus, which is commonly reported from Santonian-Campanian deposits (e.g., Goody, 1976) needs further examination. However, their very similar morphology strongly suggests that they are closely related, if not conspecific. This interpretation challenges the contention that E. shumardi was the sole Enchodus species in North America during the Cenomanian (Parris et al., 2007).

Enchodus cf. E. shumardi Leidy, 1856

Fig. $4 \mathrm{~N}$

Referred material. FHSM VP-17525, one tooth (Fig. 4N); FHSM VP-17526, 11 teeth.

Description. Teeth of this taxon are nearly straight and measure up to about $4 \mathrm{~mm}$ in height. Both cutting edges of the teeth are razor-like and continue to the base. Both lingual and labial surfaces of the teeth are smooth although the former is more convex than the latter.

Discussion. Enchodus cf. E. shumardi from the Bear Springs locality is represented only by isolated teeth, whereas $E$. shumardi is currently reported only from the Upper Cenomanian to the Middle Maastrichtian (see Shimada et al., 2006). Whether or not the Bear Springs mid-Cenomanian form is conspecific to E. shumardi needs further examination. The coexistence of the two Enchodus species, E. cf. E. gladiolus (see above) and E. cf. E. shumardi, in the Cenomanian of Colorado has been demonstrated by two distinct types of palatine bones found in the basal Lincoln Limestone (E. cf. E. gladiolus having a more anteroposteriorly elongate palatine bone than $E$. cf. E. shumardi; Shimada et al., 2006). Enchodus in general is considered to be a predaceous fish that fed on fast-swimming cephalopods (Grandstaff and Parris, 1990). Enchodus also served as an important food resource for a variety of other animals such as other teleosts and plesiosaurs (e.g., Cavin, 1999; Cicimurri and Everhart, 2001).

Suborder Ichthyotringoidei Goody, 1969

Family Ichthyotringidae Jordan, 1905

Genus Apateodus Woodward, 1901

Apateodus sp.

Fig. 40
Referred material. FHSM VP-17527, one tooth (Fig. 40); FHSM VP-17528, two teeth.

Description. Teeth from this taxon measure up to about $2 \mathrm{~mm}$ in height. They have a triangular shape with cutting edges. The teeth exhibit slightly transparent enamaloid caps on the tooth tips. They also have a slight lingual curve. The tooth, FHSM VP-17527, has a small pulp cavity at the root.

Discussion. Apateodus is so far known from three described species, the North American A. busseni Fielitz and Shimada, 2009, and the European A. glyphodus (Blake, 1863) and A. striatus (Agassiz, 1837). However, the diversity of the genus may be greater than the present fossil record suggests given that isolated bones and teeth of the genus have been sporadically reported from Albian-Maastrichtian marine deposits nearly worldwide. The genus has been reported from England, Belgium, the Netherlands, Germany, southwestern Russia, India, western Canada, western and central USA, and Bolivia (Woodward, 1901; Kruizinga, 1924; Leriche, 1929; Tolmachoff, 1942; Albers and Weiler, 1964; Goody, 1969; Wilson and Chalifa, 1989; Jaillard et al., 1993; Prasad and Godinot, 1994; Nessov, 1995; Martin et al., 1998; Ladwig, 2000; Longbottom and Patterson, 2002; Rana et al., 2005; Fielitz and Shimada, 2009). Teeth of Apateodus collected from the Bear Springs locality represent the oldest remains of the genus in North America. Whereas Apateodus was a prey item for other predatory fishes (e.g., Cicimurri and Everhart, 2001), its tooth morphology suggests that Apateodus was also a predatory fish.

Teleostei incertae sedis (Teleost A)

Fig. 4P

Referred material. FHSM VP-17529, one tooth (Fig. 4P); FHSM VP-17530, seven teeth.

Description. Teleost A teeth show a significant variation in size and a slight variation in shape. They consist of smooth-surfaced, conical crowns, which measure up to $4 \mathrm{~mm}$ in height. Most of the teeth possess a transparent enameloid cap at the apex. Teeth of this taxon are characterized by having a slender crown with a slight sigmoidal flexure and circular transverse cross sections (e.g., FHSM VP-17530). Some teeth exhibit a simple lingual curvature. Large pulp cavities generally open at the base of the tooth.

Discussion. This species is the same taxon as Teleostei incertae sedis ("Teleost A") described by Shimada et al. (2006), Shimada and Martin (2008), and Cumbaa et al. (2010). Teeth of this taxon are relatively uncommon at the Bear Springs locality. It was probably a carnivorous fish because its teeth were suited for grasping and piercing.

Teleostei incertae sedis (Teleost B)

Fig. $4 \mathrm{Q}$

Referred material. FHSM VP-17531, one tooth (Fig. 4Q); FHSM VP-17532, 16 teeth.

Description. Teeth considered here consist of a smooth crown that generally has a broad, triangular surface. They are narrowly lingual and can measure up to about $4 \mathrm{~mm}$ in height. Some teeth are erect with mesiodistal cutting edges and others are slightly curved lingually and lack the cutting edge. A few well-preserved teeth exhibit a transparent enameloid cap at the tip.

Discussion. This species is the same taxon as Teleostei incertae sedis ("Teleost B") described by Shimada et al. (2006), Shimada and 
Martin (2008), and Cumbaa et al. (2010). Among the four unidentified teleosts (Teleosts A-D), Teleost B is the most common taxon at the Bear Springs locality. However, it should be noted that a considerable range of morphological variation is recognized among the samples of this morphotype suggesting that multiple taxa may be lumped into this taxon.

Teleostei incertae sedis (Teleost C)

Fig. 4R

Referred material. FHSM VP-17533, one tooth (Fig. 4R); FHSM VP-17534, 10 teeth.

Description. These teeth are characterized by having slender conical crowns that show some irregularity in shape and longitudinal striations. The teeth measure up to $3 \mathrm{~mm}$ in height and are generally slightly curved. A few of the more complete specimens show a transparent enameloid cap on the tooth tip. The teeth have a circular transverse cross section.

Discussion. This species is the same taxon as Teleostei incertae sedis ("Teleost C") described by Shimada et al. (2006), Shimada and Martin (2008), and Cumbaa et al. (2010). Teeth of this taxon can be distinguished from other fish teeth at the Bear Springs locality from their longitudinal striations. They are suited for piercing, and the striations probably served as a strengthening feature to assist in absorbing vertical load.

Teleostei incertae sedis (Teleost D)

Fig. 4S

Referred material. FHSM VP-17535, one tooth (Fig. 4S); FHSM VP-17536, one tooth.

Description. Teeth of this taxon are conical and measure up to about $2 \mathrm{~mm}$ in height, the apical half representing a crown and the basal half its root. The presumed lingual side of the root is flat and slants where a pulp cavity is present. One of the specimens preserving the crown tip (FHSM VP-17536) shows a transparent enameloid cap. Multiple, small, erect conical cusplets are distributed on the presumed labial side near the tooth base.

Discussion. The most distinct characteristic of this taxon is the presence of multiple small, erect, conical cusplets near the tooth base. This tooth form is new to the Cenomanian fossil record in the Western Interior. It is rare at the Bear Springs locality.

Class Reptilia

Subclass Diapsida

Infraclass Lepidosauria

Order Squamata Oppel, 1811

Family Dolichosauridae Gervais, 1852

Genus Coniasaurus Owen, 1850

Coniasaurus crassidens Owen, 1850

Fig. 4T

Referred material. FHSM VP-17539, one tooth (Fig. 4T); FHSM VP-17540, 17 teeth.

Description. The specimens are mostly represented by tooth crowns that measure up to about $3.5 \mathrm{~mm}$ in height. Generally, they are bulbous and have a shallow to deep sulcus on the labial crown face, a distinctive feature of $C$. crassidens (Caldwell, 1999; Caldwell and Cooper, 1999). The base of each crown is circular to oval in outline.
Discussion. Coniasaurus crassidens was a small, slender, marine lizard, generally measuring less than $1 \mathrm{~m}$ in total length (Caldwell and Cooper, 1999) and known from Late Cretaceous Tethyan and Western Interior deposits of Germany, the United Kingdom, and the United States (Diedrich, 1997; Caldwell, 1999; Caldwell and Cooper, 1999). In North America, the species is relatively common in Cenomanian-Turonian rocks of South Dakota, Colorado, Kansas, and Texas (see Shimada and Ystesund, 2007).

\section{Discussion}

The dissolved rocks have yielded numerous isolated teeth and bones of marine vertebrates. Whereas the exact identification of the estimated 10,000 microfossils remains uncertain, 5250 of them are taxonomically identified and consist of 26 taxa comprising eight chondrichthyans (sharks and rays), 17 osteichthyans (bony fishes), and one reptile (marine lizard) (Table 1 ). Teeth of the bony fish species, Enchodus cf. E. gladiolus, followed by Pachyrhizodus minimus, are found to be the most common identifiable vertebrate fossils in the rocks. Teeth of the shark species Ptychodus anonymus are found to be the most commonly identifiable chondrichthyan fossils. In addition, bivalves, such as Exogyra aff. E. boveyensis and indeterminate inoceramid shell pieces were noted in the rocks, although much of their calcium carbonate shells were dissolved away during acid treatment.

The deposition of the Hartland Shale marks the transgressive phase of the Greenhorn Cyclothem when the Western Interior Seaway expanded (Hattin, 1975). However, the examined calcarenite slabs were observed to have many clayey fragments, and vertebrate remains were mostly isolated and fragmentary. Such calcarenite beds are thought to represent "periodic current events and/or depositional hiatuses during which skeletal debris was winnowed and concentrated" (Sageman, 1985, p. 113). Whereas these brief depositional episodes might signal periods of temporary sea-level regression, they can be similarly explained as stormwinnowed debris from especially significant wave events, as evidenced by the abundance of clayey rip-up clasts. The abundance of fossils in the calcarenite slabs is surprising given that the Hartland Shale reflects a period of deposition during which the seafloor experienced an anoxic event (Sageman, 1985).

This study represents the first analysis of a concentrated association of vertebrate fossils from the Hartland Shale (cf. Shimada and Nagrodski, 2010). Table 1 lists all of the taxa identified from the Bear Springs locality, and also shows taxa found in the base of the Lincoln Limestone that stratigraphically underlies the Hartland Shale in southeastern Colorado and central Kansas based on published data (Shimada et al., 2006; Shimada and Martin, 2008). The basal Lincoln Limestone in southeastern Colorado is of middlelate Middle Cenomanian age (ca. 95 Ma: Shimada et al., 2006), whereas that in central Kansas is inferred to be of early Late Cenomanian in age (ca. 94.6 Ma; Shimada and Martin, 2008), which is chronologically approximately equivalent to the calcarenite bed studied here. One interesting observation is that the taxonomic composition of the Lincoln Limestone fauna in Colorado and Kansas is very similar to the Hartland Shale fauna. In fact, the only species from the Hartland Shale that were not identified in both Lincoln Limestone localities are Elopopsis sp., Cimolichthys nepaholica, Apateodus sp., and "Teleostei indet. (Species D)" (Table 1).

Russell $(1988,1993)$ introduced a concept of 'North American Marine Vertebrate Ages' and he referred the mid-Cenomanian to the "Woodbinian Age", which was the onset of the "Niobraran fauna" that followed through to the early Campanian and was characterized by a high fish diversity. Cumbaa et al. (2010) elaborated upon the Woodbinian Age, which corresponds to the deposition of the basal Lincoln Limestone in Colorado and Kansas, by 
characterizing the biostratigraphical vertebrate assemblage as having the following eight chondrichthyan species: Ptychodus decurrens, P. occidentalis, Squalicorax curvatus, Cretodus semiplicatus, Carcharias amonensis, C. saskatchewanensis, Eostriatolamia tenuiplicatus, and Cretomanta canadensis. In the Hartland Shale fauna described here, only three of these eight species ( $S$. curvatus, C. saskatchewanensis, and Cretomanta canadensis) are recognized. The lack of the other five taxa may in part be a result of collecting bias because we surveyed a relatively small amount of rock. Nevertheless, the striking resemblance of the Hartland Shale fauna with that of the extensively sampled basal Lincoln Limestone of Colorado and Kansas (Table 1) suggests that it is reminiscent of the fauna of the Woodbine Age. Furthermore, the occurrence of the geologically oldest record of Apateodus and Cimolichthys nepaholica discovered in the Hartland Shale suggests that their occurrence can be interpreted to represent the onset of the Niobraran fauna where the two taxa are known from the Niobrara Chalk in western Kansas (Shimada and Fielitz, 2006; Fielitz and Shimada, 2009). If so, it may be argued that the two taxa evolved sometime between 95 and 94.6 Ma based on the present fossil record.

Based on their dental morphology, all identified bony fish taxa are small to medium-sized carnivores, consisting of presumed piscivores (Protosphyraena, Elopopsis, Caturidae, Cimolichthys, Pachyrhizodus, Enchodus, and the four unidentified teleosts) and durophagous forms (Micropycnodon, cf. Palaeobalistum, Plethodidae, and Albulidae that possibly fed on crustaceans) (e.g., see Shimada et al., 2006, and references therein). Ptychodus and Rhinobatos are durophagous chondrichthyans that presumably fed largely on shelled invertebrates. Carcharias is a small piscivorous shark, and Squalicorax, Archaeolamna, and Cretoxyrhina are sharks characterized as "large" carnivores (estimated total body length greater than $1.5 \mathrm{~m}$; see Shimada et al., 2006). Coniasaurus crassidens is a small durophagous aquatic lizard ( $<1 \mathrm{~m}$ in length; see Shimada et al., 2006). The abundance of carnivorous taxa suggests that the palaeocommunity must have been rich in organisms in lower trophic levels (e.g., small fishes and macroinvertebrates as well as phytoplankton and zooplankton) to support the carnivores as food sources.

\section{Acknowledgements}

We thank R.J. Zakrzewski (FHSM) for organizing the curation of the specimens described here, C. Fielitz for providing us with useful information, and the Environmental Science Program at DePaul University for financial support. We also thank J.A. Chamberlain, Jr., and an anonymous reviewer for making useful comments and suggestions on the manuscript that improved the quality of this paper.

\section{References}

Agassiz, L., 1833-1843 [1833, 1835, 1837, 1843]. Recherches sur les poissons fossils Volumes 1-5. Imprimerie de Patitpierre, Neuchâtel, 1420 pp.

Albers, H., Weiler, W., 1964. Eine Fischfauna aus der oberen kreide von Aachen und neuere Funde von Fischresten aus dem Maestricht des angrenzenden belgishholländischen Raumes. Neues Jahrbuch für Geologie und Paläontologie, Abhandlungen 120,1-33.

Applegate, S.P., 1970. The vertebrate fauna of the Selma Formation in Alabama. Part VIII: the fishes. Fieldiana, Geology Memoirs 3, 385-433.

Arambourg C. 1954. Les poissons crétacés du Jebel Tselfat (Maroc). Protectorat de la Republique Francaise au Maroc, Direction de la Production Industrielle et des Mines, Division des Mines et de la Géologie, Service Géologique, Notes et Mémoires 118, 188 pp.

Bardack, D., 1962. Taxonomic status and geologic position of the Cretaceous fish Ichthyodectes marathonensis. Australian Journal of Science 24, 387-388.

Bardack, D., 1968. Fossil vertebrates from the marine Cretaceous of Manitoba. Canadian Journal of Earth Sciences 5, 145-153.

Bartholomai, A., 1969. The Lower Cretaceous elopoid fish Pachyrhizodus marathonensis (Etheridge Jr.). In: Campbell, K.S.W. (Ed.), Stratigraphy and Palaeontology. Australian National University Press, Canberra, pp. 249-263.
Başusta, N., Demirhan, S.A., Karalar, M., Cekic, M., 2007. Diet of common guitarfish (Rhinobatos rhinobatos L., 1758) in Iskenderun Bay (northeastern Mediterranean). Rapports de la Commission Internationale de la Mer Méditerranée 38 426.

Berg, L.S., 1940. Classification of fishes both recent and fossil, 5. Trudy Zoologicheskogo Instituta, Akademia Nauk SSSR, Leningrad. 346-517.

Berg, L.S., 1958. System der Rezenten und Fossilen Fischartigen und Fische. Hochschulbücher für Biologie, Berlin, 310 pp.

Bergquist, H.R., 1944. Cretaceous of the Mesabi Iron Range, Minnesota. Journal of Paleontology 18, 1-30.

Biddle, J.P., Landemaine, O., 1988. Contributions à l'étude des Sélaciens du Crétacé du Bassin de Paris. In: Découverte de quelques nouvelles espèces associées à une faune de type wealdien dans le Barrémien supérieur (Crétacé inférieur) des environs de Troyes (Aube). Musée de Saint-Dizier, Saint-Dizier, Cahier, 2, 22 pp.

de Blainville, H.D., 1818. Sur les ichthyolites ou les poissons fossiles, vol. 27. Nouveau Dictionnaire d'Histoire Naturelle, Deterville, Paris. 310-395.

Blake, C.C., 1863. On the new fish jaw from the Gault near Folkestone. Geologist (London) 6, 133-134.

Bleeker, P., 1859. Enumeratio specierum hucusque in archipelago indico observatarum, vol. 6. Acta Batavia Koninklijke Naturkundige Vereeniging Netherlandsch Indie, $276 \mathrm{pp}$.

Blot, J., 1987. Studi e Ricerche sui Giacimenti Terziari di Bolca V. In: L'ordre des Pycnodontiformes. Museo Civico di Storia Naturale, Verona, 211 pp.

Caldwell, M.W., 1999. Description and phylogenetic relationships of a new species of Coniasaurus Owen, 1850 (Squamata). Journal of Vertebrate Paleontology 19, 438-455.

Caldwell, M.W., Cooper, J., 1999. Redescription, palaebiogeography, and palaeoecology of Coniasaurus crassidens Owen, 1850 (Squamata) from the English Chalk (Cretaceous; Cenomanian). Zoological Journal of the Linnean Society 127, 423-452.

Cappetta, H., Case, G.R., 1975. Sélaciens nouveaux du Crétacé du Texas. Geobios 8 303-307.

Carpenter, K., 2003. Vertebrate biostratigraphy of the Smoky Hill Chalk (Niobrara Formation) and the Sharon Springs Member (Pierre Shale). In: Harries, PJ. (Ed.) Approaches in High-Resolution Stratigraphic Paleontology. Kluwer Academic Publishers, Amsterdam, pp. 421-437.

Case, G.R., Tokaryk, T.T., Baird, D., 1990. Selachians from the Niobrara Formation of the Upper Cretaceous (Coniacian) of Carrot River, Saskatchewan, Canada. Canadian Journal of Earth Sciences 27, 1084-1094.

Casier, E., 1947. Constitution et évolution de la racine dentaire des Euselachii, II. Etude comparative des types. Bulletin du Musée Royal d'Histoire Naturelle de Belgique 23, 1-32.

Cavin, L., 1999. Occurrence of juvenile teleost, Enchodus sp., in a fish gut content from the Upper Cretaceous of Goulmima, Morocco. Palaeontology 60, 57-72

Chalifa, Y., Lewy, Z., 1991. Early Maastrichtian marine teleosts from the northern Negev, Israel. Israel Journal of Earth Sciences 40, 91-105.

Chanet, B., 1997. Plethodid remains (Osteichthyes: Teleostei incertae sedis) from the basal Albian of the Vocontian Basin (S. E. France). Neues Jahrbuch für Geologie und Paläontologie, Monatshefte 1997, 696-702.

Cicimurri, D.J., Everhart, M.J., 2001. An elasmosaur with stomach contents and gastroliths from the Pierre Shale (Late Cretaceous) of Kansas. Transactions of the Kansas Academy of Science 104, 129-143.

Cobban, W.A., Walaszczyk, I., Obradovich, J.D., McKinney, K.C., 2006. A USGS zonal table for the Upper Cretaceous middle Cenomanian-Maastrichtian of the Western Interior of the United States based on ammonites, inoceramids, and radiometric ages. US Geological Survey, Open-File Report 2006-1250, 45 pp.

Cook, T.D., Newbrey, M., Murray, A., Wilson, M.V.A., Shimada, K., Takeuchi, G., Stewart, J.D., 2011. A partial skeleton of the Late Cretaceous lamniform shark, Archaeolamna kopingensis, from the Pierre Shale of western Kansas. Journal of Vertebrate Paleontology 31, 8-21.

Cope, E.D., 1872a. On the geology and paleontology of the Cretaceous strata of Kansas. United States Geological Survey, Montana, Fifth Annual Report, pp. 318-349.

Cope, E.D., 1872b. On the families of fishes of the Cretaceous formations in Kansas. Proceedings of the American Philosophical Society 12, 327-357.

Cope, E.D., 1874. Review of the Vertebrata of Cretaceous formations found west of the Mississippi River. Section I. On the mutual relationships of the Cretaceous and Tertiary formations of the west. Section II. List of species of Vertebrata from the Cretaceous formations of the west. Bulletin of the United States Geological and Geographical Survey of the Territories 1 (2), 3-48.

Cumbaa, S.L., Tokaryk, T.T., 1999. Recent discoveries of Cretaceous marine vertebrates on the eastern margins of the Western Interior Seaway. In: Summary of Investigations 1999, Vol. 1, Miscellaneous Report 99-4.1. Saskatchewan Geological Survey, Saskatchewan Energy Mines, pp. 57-63.

Cumbaa, S.L., Schröder-Adams, C.J., Day, R.G., Phillips, A.J., 2006. Cenomanian bonebed faunas from the northeastern margin, Western Interior Seaway, Canada. In: Lucas, S.G., Sullivan, R.M. (Eds.), Late Cretaceous Vertebrates from the Western Interior. Bulletin of the New Mexico Museum of Natural History and Science 35, pp. 139-155.

Cumbaa, S.L., Shimada, K., Cook, T.D., 2010. Mid-Cretaceous vertebrate faunas of the Western Interior Seaway of North America and their evolutionary, paleobiogeographical, and paleoecological implications. Palaeogeography, Palaeoclimatology, Palaeoecology 195, 199-214.

Davis, J.W., 1890. On the fossil fish of the Cretaceous Formations of Scandinavia. Scientific Transactions of the Royal Dublin Society 4, 363-434. 
Diedrich, C., 1997. Eie Dentale von Coniosaurus crassidens Owen (Varanoidea) aus dem Ober-Cenoman von Halle/Westf. (NW-Deutschland). Geologie und Paläontologie in Westfalen 47, 43-51.

Diedrich, C., 2001. Ein Pectoralflossenrest von Protosphyraena sp. (Pachycormidae, Actinopterygii) aus dem Ober-Cenoman von Halle/Westf. (Teutoburger Wald, NW-Deutschland). Berichte des Naturwissenschaftlichen Vereins für Bielefeld und Umgegend $41,31-44$

Dixon, F., 1850. The Geology and Fossils of the Tertiary and Cretaceous Formations of Sussex. Longman, Brown, Green \& Longman, London, 408 pp.

Eicher, D.L., 1967. Depth of the Greenhorn Sea. Paleoenvironments of the Cretaceous Seaway in the Western Interior - A Symposium. Colorado School of Mines, Golden, pp. 145-172.

Everhart, M.J., 2005. Oceans of Kansas - A Natural History of the Western Interior Sea. Indiana University Press, Bloomington, IN, 322 pp.

Everhart, M.J., 2007a. Remains of a pycnodont fish (Actinopterygii: Pycnodontiformes) in a coprolite; an upper record of Micropycnodon kansasensis in the Smoky Hill Chalk, western Kansas. Transactions of the Kansas Academy of Science $110,35-43$.

Everhart, M.J., 2007b. New stratigraphic records (Albian-Campanian) of the guitarfish, Rhinobatos sp. (Chondrichthyes; Rajiformes), from the Cretaceous of Kansas. Transactions of the Kansas Academy of Science 110, 225-235.

Fielitz, C., 1996. A Late Cretaceous (Turonian) ichthyofauna from Lac des Bois, Northwest Territories, Canada, with paleobiogeographic comparisons with Turonian ichthyofaunas of the Western Interior Seaway. Canadian Journal of Earth Sciences 33, 1375-1389.

Fielitz, C., 2004. The phylogenetic relationships of the $†$ Enchodontidae (Teleostei: Aulopiformes). In: Arratia, G., Wilson, M.V.H., Cloutier, R. (Eds.), Recent Advances in the Origin and Early Radiation of Vertebrates. Verlag Dr. Friedrich Pfeil, München, pp. 619-634.

Fielitz, C., Shimada, K., 1999. A new species of Bananogmius (Teleostei: Tselfatiformes) from the Upper Cretaceous Carlile Shale of western Kansas. Journal of Paleontology 73, 504-511.

Fielitz, C., Shimada, K., 2009. A new species of Apateodus (Teleostei: Aulopiformes) from the Upper Cretaceous Niobrara Chalk of western Kansas, U.S.A. Journal of Vertebrate Paleontology 29, 650-658.

Forey, P.L., 1977. The osteology of Notelops Woodward, Rhacolepis Agassiz and Pachyrhizodus Dixon (Pisces: Teleostei). Bulletin of the British Museum of Natural History 28, 125-204.

Forey, P.L., Littlewood, D.T.J., Ritchie, P., Meyer, A., 1996. Interrelationships of elopomorph fishes. In: Stiassny, M.L.J., Parenti, L.R., Johnson, G.D. (Eds.), Interrelationships of Fishes. Academic Press, New York, NY, pp. 175-192.

Forey, P.L., Yi, L., Patterson, C., Davies, C.E., 2003. Fossil fishes from the Cenomanian (Upper Cretaceous) of Namoura, Lebanon. Journal of Systematic Palaeontology $1,227-330$.

Francis, M.P., 1996. Observations on a pregnant white shark with a review of reproductive biology. In: Klimley, A.P., Ainley, D.G. (Eds.), Great White Sharks: the Biology of Carcharodon carcharias. Academic Press, San Diego, CA, pp. 157-172.

Gallo, V., de Figueiredo, F.J., 2002. Farinichthys gigas, a new albulid fish (Teleostei: Elopomorpha) from the Paleocene of the Pernambuco-Paraíba Basin, northeastern Brazil. Journal of Vertebrate Paleontology 22, 747-758.

Garman, S., 1913. The Plagiostomia (sharks, skates and rays). Memoirs of the Museum of Comparative Zoology at Harvard College 36, 528 pp.

Gervais, P., 1852. Zoologie et Paleontologie Françaises (Animaux Vertébrés, first edition). Arthus Bertrand, Paris, pp. 271

Gill, T.N., 1893. Families and subfamilies of fishes. National Academy of Science Memoirs 6, 127-138.

Glickman, L.S., 1957. On the systematic significance of accessory denticles in the teeth of sharks of the families Lamnidae and Scapanorhynchidae. Trudy Geologischeskogo Muzeja 'A. P. Karpinskogo', Akademia Nauk SSSR 1, 103-109 (in Russian)

Glickman, L.S., 1958. Rates of evolution in lamnoid sharks. Doklady Akademia Nauk, SSSR 123, 568-571 (in Russian)

Goody, P.C., 1969. The relationships of certain Upper Cretaceous teleosts with special reference to the myctophoids. Bulletin of the British Museum (Natural History), Geology, Supplement 7, 255 pp.

Goody, P.C., 1970. The Cretaceous teleostean fish Cimolichthys from the Niobrara Formation of Kansas and the Pierre Shale of Wyoming. American Museum Noviates 2434, 1-29.

Goody, P.C., 1976. Enchodus (Teleostei: Enchodontidae) from the Upper Cretaceous Pierre Shale of Wyoming and South Dakota with an evaluation of the North American enchodontid species. Palaeontographica, Abteilung A 152, 91-112.

Grande, L., Bemis, W.E., 1998. A comprehensive phylogenetic study of amiid fishes (Amiidae) based on comparative skeletal anatomy. An empirical search for interconnected patterns of natural history: Society of Vertebrate Paleontology, Memoir 4, 690 pp.

Grandstaff, B.S., Parris, D.C., 1990. Biostratigraphy of the fossil fish Enchodus Agassiz Journal of Vertebrate Paleontology 9 (Suppl. 3), 25A.

Greenwood, P.H., Rosen, D.E., Weitzman, S.H., Meyers, G.S., 1966. Phyletic studies of teleostean fishes, with a provisional classification of living forms. Bulletin of the American Museum of Natural History 131, 339-455.

Hamm, S.A., 2010. The Late Cretaceous shark, Ptychodus rugosus (Ptychodontidae) in the Western Interior Sea. Transactions of the Kansas Academy of Science 113, 44-55.

Hattin, D.E., 1975. Stratigraphy and depositional environment of Greenhorn Limestone (Upper Cretaceous) of Kansas. Kansas Geological Survey Bulletin 209, 128 pp.
Hay, O.P., 1929. Second bibliography and catalogue of the fossil Vertebrata of North America. Publications of the Carnegie Institute of Washington 390, $2003 \mathrm{pp}$.

Heckel, J., 1856. Beiträge zur Kenntniss der fossilen Fische Österreichs. Denkschriften der Kaiserlichen Akademie der Wissenschaften, Mathematischnaturwissenschaftliche Classe 11, 187-274.

Herman, J., Hovestadt-Euler, M., Hovestadt, D.C., 1997. Contributions to the study of the comparative morphology of teeth and other relevant ichthyodorulites in living supraspecific taxa of chondrichthyan fishes. Part B: Batomorphii. No. 2: Order Rajiformes-Suborder: Pristoidei-Family: Pristidae-Genera: Anoxypristis and Pristis. No. 3: Suborder Rajoidei-Superfamily Rhinobatoidea-Families: Rhidae-Genera: Rhina and Rhynchobatus and Rhinobatidae-Genera: Aptychotrema, Platyrhina, Platyrhinoidis, Rhinobatos, Trygonorrhina, Zanobatus and Zapteryx. Bulletin de l'Institut Royal des Sciences Naturelles de Belgique, Biologie 67, 107-162.

Hibbard, C.W., Graffham, A., 1941. A new pycnodont fish from the Upper Cretaceous of Rooks County, Kansas. Quarterly Bulletin of the University of Kansas 27, 71-77.

Hibbard, C.W., Graffham, A., 1945. Micropycnodon, a new name for Pycnomicrodon Hibbard and Graffham not Hay. Transactions of the Kansas Academy of Science 47, 404.

Ismen, A., Yiğin, C., Ismen, P., 2007. Age, growth, reproductive biology and feed of the common guitarfish (Rhinobatos rhinobatos Linnaeus, 1758) in Iskenderun Bay, the eastern Mediterranean Sea. Fisheries Research 84, 263-269.

Jaekel, O., 1898. Die Selachier aus dem oberen Muschel kalk Lothringens. Abhandlungen Geologische Spezialk, Elasass-Lothringen, Series 34 , 273-332.

Jaillard, E., Cappetta, H., Ellenberger, P., Feist, M., Grambast-Ressard, N., Lefrance, J.P. Sigé, B., 1993. Sedimentology, palaeontology, biostratigraphy and correlation of the Late Cretaceous Vilquechico Group of southern Peru. Cretaceous Research $14,623-661$

Jordan, D.S., 1905. A Guide to the Study of Fishes. Henry Holt and Sons, New York NY, 589 pp.

Kauffman, E.G., 1969. Cretaceous marine cycle of the Western Interior. Mountain Geologist 6, 227-245.

Kauffman, E.G., 1977. Geological and biological overview: Western Interior Cretaceous Basin. Mountain Geologist 14, 57-99.

Kauffman, E.G., Caldwell, W.G.E., 1993. The Western Interior Basin in space and time. In: Caldwell, W.G.E., Kauffman, E.G. (Eds.), Evolution of the Western Interior Basin. Geological Association of Canada, Special Paper 39, pp. 1-30.

Kauffman, E.G., Sageman, B.B., Kirkland, J.I., Elder, W.P., Harries, P.J., Villamil, T., 1993. Molluscan biostratigraphy of the Cretaceous Western Interior Basin, North America. In: Caldwell, W.G.E., Kauffman, E.G. (Eds.), Evolution of the Western Interior Basin. Geological Association of Canada, Special Paper 39, pp. 397-434.

Kruizinga, P., 1924. Apateodus coneti (For.) in the Senonian beds of the southern part of Limburg (Netherlands). Proceedings of the Science Section of the Koninklijke Nederlandse Akademie van Wetenschappen 27, 293-312.

Ladwig, J., 2000. Fischzähne aus dem Obercampan von Kronsmoor. Der Geschiebesammler 33, 125-130.

Leidy, J., 1855. Indications of twelve species of fossil fishes. Proceedings of the Academy of Natural Sciences of Philadelphia 7, 395-397.

Leidy, J., 1856. Notice of some remains of fishes discovered by Dr. John E. Evans. Proceedings of the Academy of Natural Sciences of Philadelphia 8, 256-257.

Leidy, J., 1857a. Remarks on Saurocephalus and its allies. Transactions of the American Philosophical Society 9, 91-95.

Leidy, J., 1857b. Notices of some remains of extinct fishes. Proceedings of the Academy of Natural Sciences of Philadelphia 9, 167-168.

Leriche, M., 1929. Les Poissons du Crétacé marin de la Belgique et du Limbourg Hollandais. Bulletin de la Société Belgique de Géologie, Paléontologie et d'Hydrologie 37, 199-299.

Liggett, G.A., Shimada, K., Bennett, C.S., Schumacher, B.A., 2005. Cenomanian (Late Cretaceous) reptiles from northwestern Russell County, Kansas. Paleobios 25, 9-17.

Linck, H.F., 1790. Versuch einer Eintheilung der Fische nach den Zähnen. Magazin für das Neueste aus der Physik und Naturgeschichte, Gotha 6, 28-38.

Longbottom, A.E., Patterson, C., 2002. 14. Fishes. In: Smith, A.B., Batten, D.J. (Eds.) Fossils of the Chalk. Field Guides to Fossils 2, Second edition. Palaeontological Association, London, pp. 296-324.

Loomis, F.B., 1900. Die anatomie und die Verwandtschaft der Ganoid- und KnochenFische aus der Kreide-Formation von Kansas. Palaeontographica 46, 213-283.

Maisey, J.G., 2000. Continental break up and the distribution of fishes of western Gondwana during the Early Cretaceous. Cretaceous Research 21, 281-314.

Martin, J.E., Schumacher, B.A., Parris, D.C., Grandstaff, B.S., 1998. Fossil vertebrates of the Niobrara Formation in South Dakota. Dakoterra 5, 39-54.

Müller, A., Diedrich, C., 1991. Selachier (Pisces, Chondrichthyes) aus dem Cenomanium von Aschelon am Teutoburger Wald (Nordrhein-Westfalen, NW-Deutshland). Geologie und Paläontologie in Westfalen 20,1-104.

Muller, J., Henle, F.G.J., 1838-1841 [1838, 1839]. Systematische Beschreibung der Plagiostomen. Berlin, unpaginated.

Nelson, J.S., 1994. Fishes of the World. Third edition. John Wiley \& Sons, New York, NY $600 \mathrm{pp}$

Nessov, L.A., 1995. Dinosaurs of Northern Eurasia: New Data about Assemblages, Ecology, and Paleobiogeography. Institute for Scientific Research on the Earth's Crust, St. Petersburg State University, St. Petersburg, 156 pp. (in Russian).

Oppel, M., 1811. Die Ordnungen, Familien und Gattungen der Reptilien als Prodrom einer Naturgeschichte derselben. J. Lindauer, München, $87 \mathrm{pp}$.

Owen, R., 1850. Description of the fossil reptiles of the chalk formation. In: Dixon, F. (Ed.), The Geology and Fossils of the Tertiary and Cretaceous Formations of Sussex. Longman, Brown, Green \& Longman, London, pp. 378-404. 
Owen, R., 1860. Palaeontology; or a Systematic Summary of Extinct Animals and Their Geological Remains. A. and C. Black, Edinburgh, 420 pp.

Parris, D.C., Grandstaff, B.S., Gallagher, W.B., 2007. Fossil fish from the Pierre Shale Group (Late Cretaceous): clarifying the biostratigraphic record. In: Martin, J.E. Parris, D.C. (Eds.), The Geology and Paleontology of the Late Cretaceous Marine Deposits of the Dakotas. Geological Society of America, Special Paper 427, pp. 99-109.

Patterson, C., 1993. Osteichthyes: Teleostei. In: Benton, M.J. (Ed.). The Fossil Record, vol. 2. Chapman \& Hall, London, pp. 621-656.

Poyato-Ariza, F.J., Wenz, S., 2002. A new insight into pycnodontiform fishes. Geodiversitas 24, 139-248.

Prasad, G.V.R., Godinot, D.M., 1994. Eutherian tarsal bones from the Late Cretaceous of India. Journal of Paleontology 68, 892-902.

Rana, R.S., Kumar, K., Singh, H., Rose, K.D., 2005. Lower vertebrates from the Late Palaeocene-Earliest Eocene Akli Formation, Giral Lignite Mine, Barmer District, western India. Current Science 89, 1606-1613.

Rafinesque, C.S., 1810. Caratteri di alcuni nuovi generi e nuove specie di animali piante della Sicilia, Palermo, 105 pp.

Riggs, E.S., 1944. A new polycotylid plesiosaur. University of Kansas Science Bulletin $30,77-87$.

Robb III, A.J., 2004. Vertebrate fossils from the Upper Cretaceous (Merchantville Formation: Early Campanian) Graham Brickyard locality of New Jersey. Mosasaur 7 $75-88$

Rosen, D.E., 1973. Interrelationships of higher euteleostean fishes. In: Greenwood, P.H., Miles, R.S., Patterson, C. (Eds.). Interrelationships of Fishes. Zoological Journal of the Linnean Society, London, 53, pp. 397-513.

Russell, D.A., 1993. Vertebrates in the Western Interior Sea. In: Caldwell, W.G.E Kauffman, E.G. (Eds.), Evolution of the Western Interior Basin. Geological Association of Canada Special Paper 39, pp. 665-680.

Russell, D.A., 1988. A checklist of North American marine Cretaceous vertebrates including freshwater fishes. Royal Tyrrell Museum of Palaeontology (Drumheller, Canada) Occasional Paper 4, 1-58.

Sageman, B.B., 1985. High-resolution stratigraphy and paleobiology of the Hartland Shale Member: analysis of an oxygen-deficient epicontinental sea. In: Pratt, L.M., Kauffman, E.G., Zelt, F.B. (Eds.), Fine-grained Deposits and Biofacies of the Cretaceous Western Interior Seaway: Evidence of Cyclic Sedimentary Processes. Society Economic Paleontologists and Mineralogists, Field Trip Guidebook No. 4, pp. 110-121.

Shimada, K., 1997. Dentition of the Late Cretaceous lamniform shark, Cretoxyrhina mantelli, from the Niobrara Chalk of Kansas. Journal of Vertebrate Paleontology 17, 269-279.

Shimada, K., 2002. Teeth of embryos in lamniform sharks (Chondrichthyes: Elasmobranchii). Environmental Biology of Fishes 63, 309-319.

Shimada, K., 2008. New anacoracid shark from Upper Cretaceous Niobrara Chalk of western Kansas, U.S.A. Journal of Vertebrate Paleontology 28, 1189-1194.

Shimada, K., Fielitz, C., 2006. Annotated checklist of fossil fishes from the Smoky Hill Chalk of the Niobrara Chalk (Upper Cretaceous) in Kansas. Bulletin of the New Mexico Museum of Natural History and Science 35, 193-213.

Shimada, K., Martin, D.J., 2008. Fossil fishes from the basal Greenhorn Limestone (Upper Cretaceous: Late Cenomanian) in Russell County, Kansas. Fort Hays Studies 2, 89-103.

Shimada, K., Nagrodski, M., 2010. Occurrence of the fossil lamniform shark, Cretoxyrhina mantelli, from the Upper Cretaceous Hartland Shale, central Kansas. Transactions of the Kansas Academy of Science 113, 235-236.

Shimada, K., Rigsby, C.K., Kim, S.H., 2009. Partial skull of Late Cretaceous durophagous shark, Ptychodus occidentalis (Elasmobranchii: Ptychodontidae), from Nebraska, U.S.A. Journal of Vertebrate Paleontology 29, 336-349.

Shimada, K. Schumacher, B.A., 2003. The oldest record of the Late Cretaceous fis genus Thryptodus (Teleostei: Tselfatiiformes) from central Kansas. Transactions of the Kansas Academy of Science 106, 54-58.

Shimada, K., Schumacher, B.A., Parkin, J.A., Palermo, J.M., 2006. Fossil marine vertebrates from the lowermost Greenhorn Limestone (Upper Cretaceous:
Middle Cenomanian) in southeastern Colorado. Journal of Paleontology, Memoir 63, 1-45.

Shimada, K., Ystesund, T.K., 2007. A dolichosaurid lizard, Coniasaurus cf. C. crassidens, from the Upper Cretaceous Carlile Shale in Russell County, Kansas. Transactions of the Kansas Academy of Science 110, 236-242.

Siverson, M., 1992. Biology, dental morphology and taxonomy of lamniform sharks from the Campanian of the Kristianstad Basin, Sweden. Palaeontology 35, 519-554.

Siverson, M., 1996. Lamniform sharks of the mid Cretaceous Alinga Formation and Beedagong Claystone, western Australia. Palaeontology 39, 813-849.

Siverson, M., Lindgren, J., Kelley, L.S., 2007. Anacoracid sharks from the Albian (Lower Cretaceous) Pawpaw Shale of Texas. Palaeontology 50, 939-950.

Stewart, A., 1898. A contribution to the knowledge of the ichthyic fauna of the Kansas Cretaceous, vol. 7. Kansas University Quarterly. 22-29.

Stewart, A., 1899. Pachyrhizodus minimus, a new species of fish from the Cretaceous of Kansas, vol. 8. Kansas University Quarterly. 37-38.

Stewart, A., 1900. Teleosts of the Upper Cretaceous, vol. 6. University Geological Survey of Kansas. 257-403.

Stewart, J.D., 1988. The stratigraphic distribution of Late Cretaceous Protosphyraena in Kansas and Alabama. Fort Hays Studies (third series) 10, 80-94.

Stewart, J.D., Bell Jr., G.L., 1994. North America's oldest mosasaurs are teleosts. Contributions to Science. Natural History Museum of Los Angeles County 441, 1-9.

Stewart, J.D., Carpenter, K., 1990. Examples of vertebrate predation on cephalopods in the Late Cretaceous of the Western Interior. In: Boucot, A.J. (Ed.), Evolutionary Paleobiology and Coevolution. Elsevier, Amsterdam, pp. 203-206.

Tolmachoff, I.P., 1942. Upper Cretaceous fauna of the Asphalt Ridge, Utah. Annals of the Carnegie Museum 29, 41-60.

Trbušek, J., 1999. Upper Cretaceous sharks and rays from the Prokop opencast mine at Březina near Moravská Třebová. Acta Universitatis Palackianae Olomucensis, Facultas Rerum Naturalium, Geologia 36, 51-61.

Underwood, C.J., Cumbaa, S.L., 2010. Chondrichthyans from a Cenomanian (Late Cretaceous) bonebed, Saskatchewan, Canada. Palaeontology 53, 903-944.

Vullo, R., Bernárdez, E., Buscalioni, A.D., 2009. Vertebrates from the middle?-late Cenomanian La Cabaña Formation (Asturias, northern Spain): palaeoenvironmental and palaeobiogeographic implications. Palaeogeography, Palaeoclimatology, Palaeoecology 276, 120-129.

Welton, B.J., Farish, R.F., 1993. The Collector's Guide to Fossil Sharks and Rays from the Cretaceous of Texas. Before Time, Lewisville, TX, 204 pp.

Whitley, G.P., 1939. Taxonomic notes on sharks and rays. Australian Journal of Zoology 9, 227-262.

Wiffen, J., 1983. The first record of Pachyrhizodus caninus Cope (order Clupeiformes) from the Late Cretaceous of New Zealand. New Zealand Journal of Geology and Geophysics 26, 109-119.

Williston, S.W., 1900a. Some fish teeth from the Kansas Cretaceous, vol. 9. Kansas University Quarterly. 27-42.

Williston, S.W., 1900b. Cretaceous fishes, selachians and ptychodonts, vol. 6. University Geological Survey of Kansas. 237-255.

Wilson, M.V.H., Chalifa, Y., 1989. Fossil marine actinopterygian fishes from the Kaskapau Formation (Upper Cretaceous: Turonian) near Watino, Alberta. Canadian Journal of Earth Sciences 26, 2604-2620.

Witzke, BJ 1981. Cretaceous vertebrate fossils of Iowa and nearby areas of Nebraska, South Dakota and Minnesota. In: Brenner, R.L., Bretz, R.F., Bunker, B.J., Iles, D.L., Ludvigson, G.A., McKay, R.M., Whitley, D.L., Witzke, B.J. (Eds.), Cretaceous Stratigraphy and Sedimentation in Northwest Iowa, Northeast Nebraska, and Southeast South Dakota. Iowa Geological Survey, Guidebook Series, vol. 4, pp. 105-122.

Woodward, A.S., 1895. Catalogue of the Fossil Fishes in the British Museum. Pt. 3. British Museum of Natural History, London, 544 pp.

Woodward, A.S., 1901. Pt. 4. Catalogue of the fossil fishes in the British Museum (Natural History), vol. 17. Trustees of the British Museum (Natural History), London, $636 \mathrm{pp}$.

Woodward, A.S., 1902-1912 [1902, 1908]. The Fossil Fishes of the English Chalk, vols. 1-7. Palaeontographical Society, London, 264 pp. 